\title{
Design, Synthesis, and Characterization of N-Oxide-Containing Heterocycles with in Vivo Sterilizing Antitubercular Activity
}

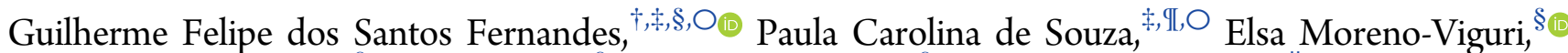
Mery Santivañez-Veliz, ${ }^{\S}$ Rocio Paucar, ${ }^{\S}$ Silvia Pérez-Silanes, ${ }^{\S \odot}$ Konstantin Chegaev,,${ }^{\| \odot}$ Stefano Guglielmo, ${ }^{\odot}$ Loretta Lazzarato, ${ }^{\circ \odot ~ R o b e r t a ~ F r u t t e r o, " ~ C h u n g ~ M a n ~ C h i n, ~}{ }^{\ddagger}$ Patricia Bento da Silva, Marlus Chorilli, ${ }^{\ddagger \oplus}$ Mariana Cristina Solcia, ${ }^{\ddagger}$ Camila Maríngolo Ribeiro, ${ }^{\ddagger}$ Caio Sander Paiva Silva, ${ }^{\ddagger}$ Leonardo Biancolino Marino, ${ }^{\ddagger}$ Priscila Longhin Bosquesi, ${ }^{\ddagger}$ Debbie M. Hunt, ${ }^{\perp}$ Luiz Pedro S. de Carvalho, ${ }^{\perp}$ Carlos Alberto de Souza Costa, "Sang Hyun Cho, "I Yuehong Wang, "Scott Gary Franzblau, ${ }^{\text {, }}$ Fernando Rogério Pavan, ${ }^{*}, *$ and Jean Leandro dos Santos $*, *, \neq \odot$

${ }^{\dagger}$ São Paulo State University (UNESP), Institute of Chemistry, Araraquara 14800060, Brazil

${ }^{\ddagger}$ São Paulo State University (UNESP), School of Pharmaceutical Sciences, Araraquara 14800903, Brazil

${ }^{\S}$ Universidad de Navarra, Department of Organic and Pharmaceutical Chemistry, Instituto de Salud Tropical, Pamplona 31008, Spain

"Dipartimento di Scienza e Tecnologia del Farmaco, Università degli Studi di Torino, Turin 10124, Italy

${ }^{\perp}$ Mycobacterial Metabolism and Antibiotic Research Laboratory, The Francis Crick Institute, 1 Midland Road,

London NW1 1AT, United Kingdom

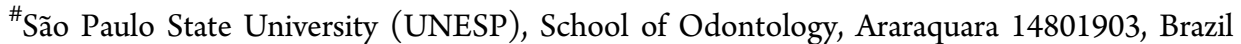

${ }^{\mathbb{I}}$ Institute of Tuberculosis Research, University of Illinois at Chicago, Chicago, Illinois 60607, United States

Supporting Information

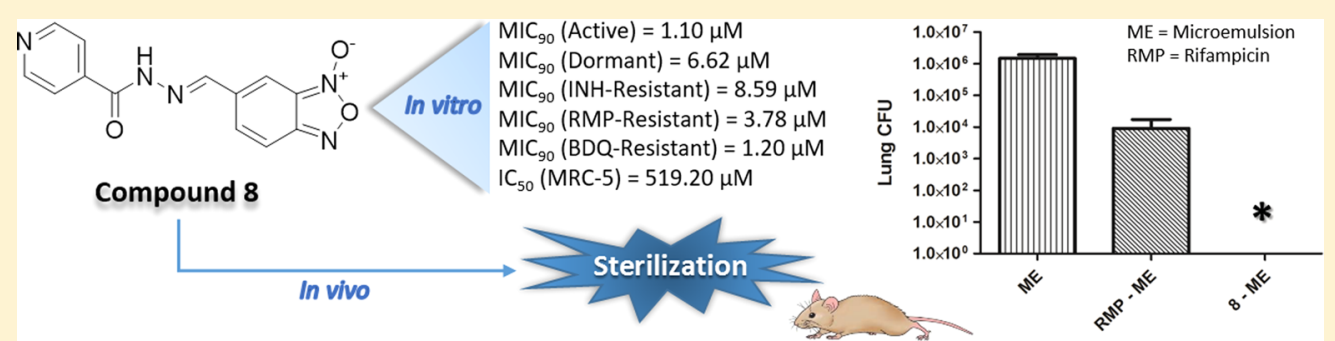

ABSTRACT: Tuberculosis, caused by Mycobacterium tuberculosis (Mtb), is the infectious disease responsible for the highest number of deaths worldwide. Herein, 22 new N-oxide-containing compounds were synthesized followed by in vitro and in vivo evaluation of their antitubercular potential against $M t b$. Compound $\mathbf{8}$ was found to be the most promising compound, with $\mathrm{MIC}_{90}$ values of 1.10 and $6.62 \mu \mathrm{M}$ against active and nonreplicating $\mathrm{Mtb}$, respectively. Additionally, we carried out in vivo experiments to confirm the safety and efficacy of compound 8; the compound was found to be orally bioavailable and highly effective, leading to a reduction of $M t b$ to undetectable levels in a mouse model of infection. Microarray-based initial studies on the mechanism of action suggest that compound 8 blocks translation. Altogether, these results indicate that benzofuroxan derivative $\mathbf{8}$ is a promising lead compound for the development of a novel chemical class of antitubercular drugs.

\section{INTRODUCTION}

Mycobacterium tuberculosis $(\mathrm{M} t \mathrm{~b})$, the causative agent of tuberculosis (TB) in humans, is considered to be responsible for the highest number of deaths caused by an infectious disease worldwide in 2015. The World Health Organization (WHO) reported 9.6 million new cases and 2 million deaths worldwide in the same year. ${ }^{1}$ The high mortality rate of TB has even surpassed the number of deaths caused by human immunodeficiency virus. According to an estimate, one-third of the world's population is infected with a latent form of $\mathrm{TB},{ }^{2}$ for which treatment is often ineffective owing to a lack of drugs with the ability to act on mycobacteria in the dormant state.
Furthermore, the increased dissemination of multidrugresistant (MDR), extensively drug-resistant, and totally drugresistant strains has posed a huge challenge throughout the world in the fight against $\mathrm{TB}^{5-8}$

For treating $\mathrm{TB}$, the $\mathrm{WHO}$ recommends a combination of isoniazid (INH), rifampicin (RMP), ethambutol, and pyrazinamide for 6 months. For cases involving resistance, the treatment can be extended up to 28 months and include the use of secondline drugs, such as fluoroquinolones, aminoglycosides, D-cycloserine,

Received: September 6, 2017

Published: October 2, 2017 

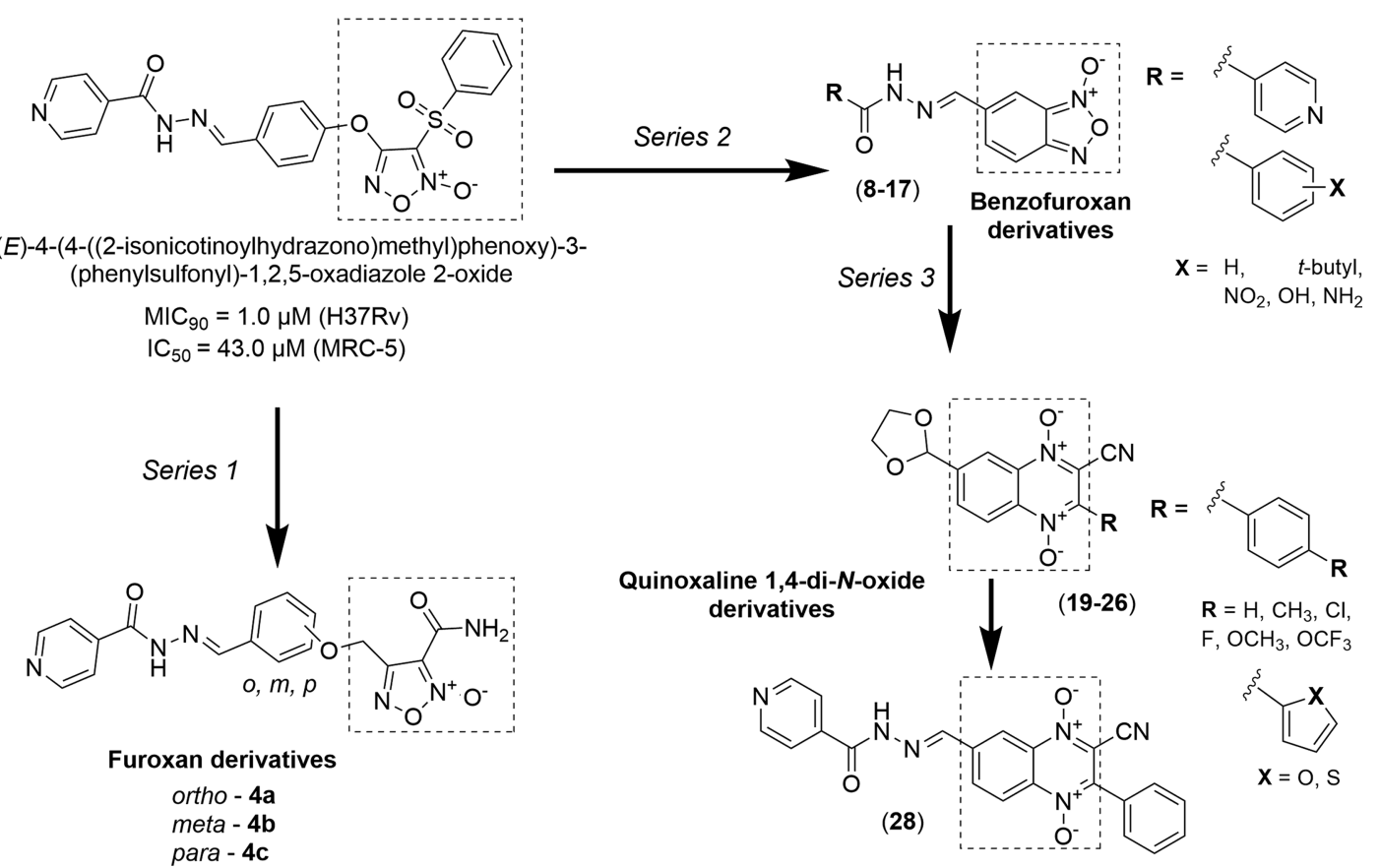

Figure 1. Design of the N-oxide-containing heterocycle derivatives.

and linezolid, among others. ${ }^{9-11}$ The current treatment suffers from several limitations, including the prolonged standard regimen, the high rate of treatment discontinuation, adverse effects, toxicity, drug-drug interactions, and a lack of effectiveness against the latent mycobacteria. ${ }^{2,12-16}$

Over the past few years, limited but significant progress in the development of drug candidates against TB has been achieved. After a gap of more than 50 years without new drugs approved for TB, the United States Food and Drug Administration approved bedaquiline (Bdq, SIRTURO, Janssen; Beerse, Belgium) in 2012 for the treatment of MDR-TB. The literature over the past 5 years has indicated significant advances in the development of other compounds with potent antitubercular activity. ${ }^{17-20}$ In this regard, several drug candidates were moved toward clinical trials, such as sutezolid, posizolid, delamanid, and pretomanid. ${ }^{21,22}$ Nevertheless, $M t b$ strains resistant to the new compounds have already been reported, ${ }^{23-25}$ reinforcing the urgency to develop more potent and a larger number of novel drugs for the treatment of TB. ${ }^{11}$

We previously reported a series of furoxan derivatives with potent activity against $M t b$, including MDR strains. Specifically, the compound (E)-4-(4-((2-isonicotinoylhydrazono)methyl)phenoxy)-3-(phenylsulfonyl)-1,2,5-oxadiazole 2-oxide (Figure 1) inhibited the growth of $M t b$ strain $\mathrm{H} 37 \mathrm{Rv}$ by $90 \%$ at a concentration of $1 \mu \mathrm{M}$. In addition, we determined that the antitubercular activity of this furoxan derivative was related to its ability to generate nitric oxide (NO) following biotransformation. ${ }^{26}$

Motivated by preliminary promising results obtained with the furoxan derivatives, we designed new heterocyclic analogues containing the $\mathrm{N}$-oxide subunit, including amide-furoxans (series 1 ), benzofuroxans (series 2), and quinoxaline 1,4-di-N-oxide (QdNO) (series 3, Figure 1). Furoxans, benzofuroxans, and QdNO derivatives represent important scaffolds in medicinal chemistry due to their wide spectrum of biological activities, ${ }^{27}$ including antitubercular activity. ${ }^{28}$ The antimycobacterial activity of these compounds is attributed to the generation of reactive oxygen species (ROS) following their biotransformation. ${ }^{29-31}$ For quinoxalines specifically, earlier studies have reported that these compounds lead to increased levels of ROS under hypoxic conditions, which could contribute to interesting properties against latent $\mathrm{TB} .{ }^{32-34}$

ROS play a crucial role in the pathogenesis of TB. Several studies have demonstrated the relationship between the level of ROS produced by immune cells and the susceptibility of a patient to several species of the Mycobacterium genus. ${ }^{35,36}$ Furthermore, the effects exerted by ROS during TB are many-fold. For example, increased ROS levels can lead to inhibition of $M t b$ growth, damage to cellular components, such as lipids, proteins, and nucleic acids, and activation of macrophage-mediated inflammatory activity. ${ }^{37-40}$ High levels of ROS can also induce apoptosis of macrophages (host for tubercle bacilli), thereby preventing the growth and replication of the bacilli. ${ }^{41}$ Therefore, the design of new compounds that could act by increasing the levels of ROS and perturbing mycobacterial redox homeostasis seems to be a promising strategy for combating TB. ${ }^{42-44}$

In a continuing effort to develop new drug candidates for the treatment of $\mathrm{TB}$, we herein describe the design, synthesis, and biological activities of a series of heterocyclic compounds containing $\mathrm{N}$-oxide as antitubercular compounds.

\section{RESULTS AND DISCUSSION}

Chemistry. Twenty-two novel compounds containing the $\mathrm{N}$-oxide subunit were synthesized according to the synthetic methodologies presented in Schemes 1, 2, and 3.

Amide-furoxan derivatives $\mathbf{1}$ and $\mathbf{2}$ were synthesized according to previously described methods. ${ }^{45,46}$ Furoxan derivative $\mathbf{2}$ was allowed to react with 2-, 3-, or 4-hydroxybenzaldehyde in dichloromethane, using 1,8-diazabicyclo[5.4.0] undec-7-ene (DBU) as the base, leading to the formation of furoxan derivatives containing an aldehyde group $(3 \mathbf{a}-\mathbf{c}){ }^{47}$ Then, a condensation reaction of the aldehyde derivatives with isonicotinohydrazide was performed in ethanolic medium catalyzed by an acid to generate hybrid furoxan derivatives $\mathbf{4 a - c}$ (Scheme 1).

The benzofuroxan derivative containing an aldehyde group (7) was obtained according to a previously reported methodology. 48 
Scheme 1. Preparation of the Compounds of Series $1^{a}$<smiles>Cc1noc(CO)c1C(N)=O</smiles>

(1)<smiles>NC(=O)c1c(CBr)no[n+]1[O-]</smiles>

(2) b)<smiles></smiles>

(3a) - ortho (3b) - meta (3c) - para<smiles>NNC(=O)c1ccncc1</smiles><smiles></smiles>

${ }^{a}$ Reagents and conditions: (a) thionyl bromide, DMF, rt, 30 min; (b) DBU, 2, 3, or 4-hydroxybenzaldehyde, DCM, rt, 1 h; (c) ethanol, acetic acid, $\mathrm{rt}, 12 \mathrm{~h}$.

\section{Scheme 2. Preparation of the Compounds of Series $2^{a}$}<smiles>O=Cc1ccc(Cl)c([N+](=O)[O-])c1</smiles>

(5)<smiles>Nc1ccc(C=O)cc1[N+](=O)[O-]</smiles>

(6)<smiles>[R]C(=O)NN</smiles><smiles>[R]Cc1ccncc1</smiles>
(8)

$X=4-\mathrm{H}$ (9), 4-tert-Butyl (10), 4- $\mathrm{NO}_{2}$ (11), 2-OH (12), 3-OH (13), 4-OH (14), 2- $\mathrm{NH}_{2}$ (15), 3- $\mathrm{NH}_{2}$ (16), 4- $\mathrm{NH}_{2}$ (17)

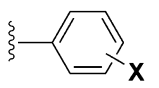

${ }^{a}$ Reagents and conditions: (a) $\mathrm{NaN}_{3}$, DMSO, $75^{\circ} \mathrm{C}, 1 \mathrm{~h}$; (b) toluene, reflux, $2 \mathrm{~h}$; (c) aromatic hydrazide, ethanol, acetic acid, rt, $12 \mathrm{~h}$.

Scheme 3. Preparation of the Compounds of Series $3^{a}$<smiles>O=Cc1ccc2no[n+]([O-])c2c1</smiles>

(7)<smiles>[131I-]</smiles><smiles></smiles>

(18)<smiles>[R]CC(C)=O</smiles>

$\ominus$<smiles>[X]c1ccc(C(C)(C)C)cc1</smiles>

$\mathbf{X}=\mathrm{H}(\mathbf{1 9}), \mathrm{CH}_{3}$ (20),

$\mathrm{Cl}$ (21), $\mathrm{OCH}_{3}$ (22), $\mathrm{F}$ (23), $\mathrm{OCF}_{3}(\mathbf{2 4})$<smiles>[Y]c1ccccc1</smiles>
$\mathrm{X}=\mathrm{O}$ (25), S (26)<smiles>N#Cc1c(-c2ccccc2)[n+]([O-])c2cc(/C=N/NC(=O)c3ccncc3)c(C=O)cc2[n+]1[O-]</smiles>

${ }^{a}$ Reagents and conditions: (a) toluene, ethylene glycol, p-toluenesulfonic acid, reflux, $12 \mathrm{~h}$; (b) $\mathrm{DCM}, \mathrm{K}_{2} \mathrm{CO}_{3}, 40{ }^{\circ} \mathrm{C}, 96 \mathrm{~h}$; (c) acetone, $\mathrm{HCl}$, rt, $48 \mathrm{~h}$; (d) isonicotinohydrazide, ethanol, acetic acid, rt, $12 \mathrm{~h}$.

The compound was allowed to react with different aromatic hydrazides through the same condensation reaction described above, leading to the formation of benzofuroxan derivatives 817 (Scheme 2). The ${ }^{1} \mathrm{H}$ and ${ }^{13} \mathrm{C}$ nuclear magnetic resonance (NMR) spectra of these compounds displayed proton and carbon signals from the benzofuroxan nucleus as broad peaks, indicating benzofuroxan tautomerism. ${ }^{27,31}$

Dioxolan-benzofuroxan derivative $\mathbf{1 8}$ was obtained from the reaction between compound 7 and ethylene glycol. ${ }^{49}$ The quinoxaline derivatives were obtained through a variation of the Beirut reaction, ${ }^{50-52}$ wherein dioxolan-benzofuroxan derivative 18 was reacted with the appropriate nitrile derivatives in dichloromethane. Potassium carbonate $\left(\mathrm{K}_{2} \mathrm{CO}_{3}\right)$ was utilized as a catalyst, ${ }^{53}$ leading to the generation of quinoxaline derivatives 19-26. Compound 28 was synthesized from quinoxaline 19, which was submitted to cyclic acetal hydrolysis followed by its reaction with isonicotinohydrazide through a condensation reaction (Scheme 3). ${ }^{54}$ 
All compounds were characterized by elemental analysis, infrared (IR) spectroscopy, mass spectrometry, and ${ }^{1} \mathrm{H}$ and ${ }^{13} \mathrm{C}$ NMR. Furthermore, all compounds were analyzed by highpressure liquid chromatography (HPLC), and their purity was confirmed to be greater than $98.5 \%$. Experimental $\log P$ values and melting points were determined for the final compounds.

Biological Studies. The antitubercular activity of compounds containing $\mathrm{N}$-oxide $(4 \mathrm{a}-\mathrm{c}, \mathbf{8}-\mathbf{1 7}, \mathbf{1 9 - 2 6}$, and 28) was assessed using $M t b$ strain $\mathrm{H}_{37} \mathrm{Rv}$ (ATCC 27294). The Resazurin microtiter assay (REMA) was employed as described previously. ${ }^{26,55}$ The results are expressed as minimum inhibitory concentration $\left(\mathrm{MIC}_{90}\right)$, and compounds showing $\mathrm{MIC}_{90}$ values below $10 \mu \mathrm{M}$ were selected for further characterization. The potential cytotoxicity of the compounds was evaluated using the MRC-5 human lung fibroblast cell line according to a previously reported methodology, ${ }^{26,56}$ and the results are expressed as $\mathrm{IC}_{50}$ values. The selectivity index (SI) of the tested compounds was calculated through the ratio of $\mathrm{IC}_{50}$ to $\mathrm{MIC}_{90}$. The compounds that reported $\mathrm{SI} \geq 10$ were considered promising for further studies according to the cutoff value established. ${ }^{56,57}$ Potential anaerobic activity of the best compounds was evaluated using the method described by Cho et al. ${ }^{58}$

Analysis of the spectrum of biological activities of the compounds was performed through determination of $\mathrm{MIC}_{90}$ values against Escherichia coli (ATCC 25922) and Staphylococcus aureus (ATCC 29213) by measuring the optical density (OD) at $570 \mathrm{~nm}\left(\mathrm{OD}_{570}\right)$ after $16 \mathrm{~h}$ and against Candida albicans (ATCC $10231)$ at $\mathrm{OD}_{570}$ after $48 \mathrm{~h}$.

The compounds were also tested against isogenic $M t b \mathrm{H}_{37} \mathrm{Rv}$ strains monoresistant to RMP (ATCC 35838), INH (ATCC 35822), streptomycin (SM, ATCC 35820), capreomycin (CAP), moxifloxacin (MOX), and BDQ (strains were from the University of Illinois at Chicago Institute for Tuberculosis Research) by the multiple antigen blot assay (MABA) microdilution technique. ${ }^{59}$ Following this step, we selected the best compound (compound 8) for further studies.

Due to the ability of $M t b$ to survive inside macrophages, we decided to investigate whether compound $\mathbf{8}$ could inhibit the growth of $M t b$ strain H37Rv in the J774A.1 macrophage cell line. Furthermore, time-kill experiments were performed for up to 15 days to evaluate the bactericidal profile of compound 8 .

Some earlier reports ${ }^{60,61}$ indicated that the growth of mycobacteria can be affected by the presence of ions and nutrients as well as by the $\mathrm{pH}$ of the medium. For this reason, different culture medium conditions were analyzed by MABA. These included (a) adjusting the culture medium to $\mathrm{pH} 6.0$, (b) including $4 \%$ bovine serum albumin (BSA), and (c) supplementing with $10 \%$ fetal bovine serum (FBS). The slightly acidic $\mathrm{pH}(\mathrm{pH}$ 6.0) was selected because it is compatible with the growth of $M t b$ and corresponds to that at the time when $M t b$-containing phagosomes fuse with lysosomes. One of the physiological functions of albumin (synthesized in the liver) is to transport poorly soluble molecules of both endogenous and exogenous origins. ${ }^{62}$ Albumin binding constitutes an essential pharmacological parameter that affects the mechanism of action (MOA) of antibiotics in humans. ${ }^{63}$ We utilized FBS, as it serves as a growth factor for mammalian cells and might interfere with the antitubercular action of some compounds.

Preliminary ADMT (absorption, distribution, and metabolism) studies were performed for compound 8 using the following in vitro assays: chemical stability, plasma protein binding, caco-2 permeability, cytochrome P450 inhibition, and hepG2 cytotoxicity. Additionally, we characterized the mutagenicity of compound 8 through a micronucleus assay using mouse peripheral blood reticulocytes.

To ensure greater stability and improved solubility, compound $\mathbf{8}$ was evaluated in an in vivo assay using a pharmaceutical formulation. The nanostructured lipid system (ME) was synthesized as described by our group previously, ${ }^{64}$ with the following composition: $10 \%$ oil phase (cholesterol), 10\% surfactant (a mixture of soy phosphatidylcholine, sodium oleate, and Eumulgin HRE 40 [polyoxyl 40 castor oil-hydrogenated]; 3:6:8), and 80\% aqueous phase (phosphate buffer, $\mathrm{pH} 7.4$ ). The compounds studied were incorporated at the desired concentration for the in vivo experiments by mass solubilization at the respective volume and sonicated for $3 \mathrm{~min}$ in batch mode at $15 \%$ amplitude. The ME-containing compound $\mathbf{8}$ was analyzed for tolerability and oral bioavailability following the treatment of female BALB/C mice infected with $M t b$.

Microarrays have been used to successfully define the MOA of antitubercular compounds. ${ }^{65}$ Therefore, a microarray analysis was performed to obtain an unbiased view of the MOA of compound 8.

In Vitro Antimycobacterial Activity. The ability of $M t b$ to remain dormant serves as the predominant factor that contributes to precluding sterilization with antibiotic therapy and promotes the development of antibiotic resistance. ${ }^{6,67}$ Therefore, an ideal antitubercular drug should (i) reduce the duration of treatment, (ii) be active against resistant strains, (iii) not interfere with other TB drugs and antiretrovirals, and (iv) be active against "dormant" bacilli. ${ }^{10}$

Recently, our research group identified the compound (E)-4(4-((2-isonicotinoylhydrazono)methyl)phenoxy)-3-(phenylsulfonyl)-1,2,5-oxadiazole 2-oxide as a promising antitubercular drug candidate. ${ }^{26}$ To optimize its antimycobacterial activity, we designed novel heterocyclic compounds containing $\mathrm{N}$-oxide analogues of the parent compound, which comprised the following heterocyclic moieties: amide-furoxan (series $1, \mathbf{4 a}-\mathbf{c}$ ), benzofuroxan (series 2, 8-17), and quinoxaline 1,4-di-N-oxide (series 3, 19-26 and 28). The amide-furoxan derivatives $(\mathbf{4 a - c})$ were selected to evaluate whether the replacement of the phenylsulfonyl group from the parent compound by an amide group would increase the antitubercular activity and/or decrease the cytotoxicity. The three amide-furoxan regioisomers $(4 a-c)$ displayed improved antitubercular activity compared to that of the parent compound. ${ }^{26}$ The compounds from series 1 exhibited $\mathrm{MIC}_{90}$ values around $0.4 \mu \mathrm{M}$ against actively growing $M t b$ strain $\mathrm{H}_{37} \mathrm{Rv}$ (Table 1).

The benzofuroxan moiety (series $2,8-17$ ) was selected due to its possible ability to generate ROS after its metabolism. ${ }^{30}$ The structural design of the series under study was based on the isosteric replacement of substituents attached on the phenyl ring. These included hydrogen, nitro, tert-butyl, amino, and hydroxyl groups. Furthermore, we evaluated the substitution of the phenyl ring by a pyridine ring owing to the presence of a heterocyclic pyridine ring in the structure of several antituberculosis drugs and bioactive compounds, such as INH, $\mathrm{BDQ}$ and ethionamide. ${ }^{68}$ As expected, the replacement of the phenyl ring of compound 9 by a pyridine ring in compound 8 led to a 7-fold increase in the antituberculosis activity $\left(\mathrm{MIC}_{90}=\right.$ $1.1 \mu \mathrm{M}$; Table 1).

Among the benzofuroxan series, our group identified the compound (E)-6-((2-isonicotinoylhydrazono)methyl)benzo$[c][1,2,5]$ oxadiazole 1 -oxide $(8)$ as the lead benzofuroxan derivative with $\mathrm{MIC}_{90}$ values of 1.1 and $6.6 \mu \mathrm{M}$ against actively growing and dormant $M t b$, respectively. The nearly equimolar 
Table 1. Antitubercular Activity of N-Oxide-Containing Heterocycles against Actively Replicating and Dormant M. tuberculosis $\mathrm{H}_{37} \mathrm{Rv}\left(\mathrm{MIC}_{90}\right)$, Cytotoxicity against the MRC-5 Cell Line $\left(\mathrm{IC}_{50}\right)$, Selectivity Index (SI), and Experimental LogP

\begin{tabular}{|c|c|c|c|c|c|c|c|c|c|}
\hline \multirow[b]{2}{*}{ class } & \multirow[b]{2}{*}{ compound } & \multicolumn{2}{|c|}{$\mathrm{MIC}_{90}$} & \multicolumn{2}{|c|}{ dormant $\mathrm{MIC}_{90}$} & \multicolumn{2}{|c|}{ cytotoxicity $\mathrm{IC}_{50}$} & \multirow[b]{2}{*}{$\mathrm{SI}^{a}$} & \multirow[b]{2}{*}{$\log \mathrm{P}^{b}$} \\
\hline & & $\mu \mathrm{g} / \mathrm{mL}$ & $\mu \mathrm{M}$ & $\mu \mathrm{g} / \mathrm{mL}$ & $\mu \mathrm{M}$ & $\mu \mathrm{g} / \mathrm{mL}$ & $\mu \mathrm{M}$ & & \\
\hline \multirow[t]{3}{*}{ furoxan } & $4 a$ & 0.16 & 0.42 & 2.95 & 7.72 & 326.70 & 854.00 & 2033.30 & 1.3 \\
\hline & $4 b$ & 0.15 & 0.40 & 1.60 & 4.20 & 490.10 & 1281.90 & 3204.70 & 1.3 \\
\hline & $4 \mathrm{c}$ & 0.16 & 0.43 & 0.78 & 2.04 & 443.30 & 1159.50 & 2696.50 & 1.3 \\
\hline \multirow[t]{10}{*}{ benzofuroxan } & 8 & 0.31 & 1.10 & - & 6.62 & 147.10 & 519.20 & 472.0 & 1.5 \\
\hline & 9 & 2.40 & 8.30 & - & - & 36.80 & 130.40 & 15.60 & 2.2 \\
\hline & 10 & 1.30 & 3.90 & - & - & 8.50 & 25.20 & 6.30 & 3.8 \\
\hline & 11 & 1.73 & 5.29 & - & - & - & - & - & 0.9 \\
\hline & 12 & 16.40 & $>62.0$ & - & - & - & - & - & 1.3 \\
\hline & 13 & $>25.0$ & $>62.0$ & - & - & - & - & - & 1.2 \\
\hline & 14 & $>25.0$ & $>62.0$ & - & - & - & - & - & 1.2 \\
\hline & 15 & 3.70 & 12.30 & - & - & 36.40 & 122.40 & 9.90 & 2.0 \\
\hline & 16 & 5.30 & 17.80 & - & - & 24.40 & 82.10 & 4.60 & 1.4 \\
\hline & 17 & 3.16 & 10.66 & $>10.0$ & $>10.0$ & 250.0 & 841.0 & 78.90 & 1.2 \\
\hline \multirow[t]{9}{*}{ quinoxaline } & 19 & 10.30 & 30.80 & - & - & 10.70 & 31.90 & 0.90 & 0.7 \\
\hline & 20 & 5.70 & 16.50 & - & - & 6.20 & 17.20 & 1.10 & 1.6 \\
\hline & 21 & 6.40 & 16.20 & - & - & 5.00 & 12.60 & 0.80 & 1.8 \\
\hline & 22 & 4.40 & 12.00 & - & - & 5.50 & 15.00 & 1.20 & 1.4 \\
\hline & 23 & 8.60 & 24.30 & - & - & 7.70 & 21.80 & 0.90 & 1.3 \\
\hline & 24 & 6.50 & 15.40 & - & - & 28.00 & 66.80 & 4.30 & 2.2 \\
\hline & 25 & 1.70 & 5.20 & - & - & 11.60 & 35.70 & 6.80 & 2.0 \\
\hline & 26 & 4.10 & 12.10 & - & - & 5.90 & 17.30 & 1.40 & 1.9 \\
\hline & 28 & 16.30 & 39.70 & - & - & 8.60 & 21.00 & 0.50 & 1.0 \\
\hline \multirow{2}{*}{ standard drugs } & isoniazid & 0.014 & 0.1 & - & 1.108 .4 & - & - & - & - \\
\hline & rifampicin & 0.082 & 0.1 & - & 0.1 & N.D. & N.D. & N.D. & N.D. \\
\hline
\end{tabular}

${ }^{a} \mathrm{SI}$ indicates the ratio between the $\mathrm{IC}_{50}$ against MRC-5 and the $\mathrm{MIC}_{90}$; dash (-) indicates not determined. ${ }^{b}$ Determined by partition coefficient (n-octanol/water) (HPLC method). ${ }^{74}$

effects observed against replicating and nonreplicating $M t b$, suggested by the small difference in $\mathrm{MIC}_{90}$ values, is considered to be an attractive characteristic. Such differences are rarely observed but highly desired and beneficial.

Moreover, our data revealed that the presence of bulky groups, such as tert-butyl $\left(\mathbf{1 0}, \mathrm{MIC}_{90}=3.9 \mu \mathrm{M}\right)$, and electronwithdrawing groups, such as nitro $\left(11, \mathrm{MIC}_{90}=5.3 \mu \mathrm{M}\right)$, led to an improvement in antituberculosis activity of the analyzed compounds. Compound 9 (unsubstituted phenyl) presented an $\mathrm{MIC}_{90}$ value of $8.3 \mu \mathrm{M}$, whereas the hydroxyl regioisomers (12-14) presented $\mathrm{MIC}_{90}$ values greater than $62 \mu \mathrm{M}$. Amino derivatives 15-17 also exhibited a reduction in antitubercular activity in comparison to that of nonsubstituted compound 9; however, these compounds reported $\mathrm{MIC}_{90}$ values $(12.3-27.9 \mu \mathrm{M})$ lower than those containing a hydroxyl substitution (Table 1).

With respect to the quinoxaline 1,4-di-N-oxide series, we evaluated the influence of electron-withdrawing and electrondonating groups on the phenyl ring on antitubercular activity. We also performed an isosteric substitution of the phenyl ring by furan (25) and thiophen (26) moieties. For quinoxaline-phenyl derivatives 19-24, the $\mathrm{MIC}_{90}$ values ranged from 12.0 to $30.8 \mu \mathrm{M}$, implying a contribution of the presence of substitution at the para position of the phenyl ring to the antituberculosis activity. Since compound 19 was devoid of any substituents, it displayed a lower potency among the phenyl quinoxaline derivatives with an $\mathrm{MIC}_{90}$ of $30.8 \mu \mathrm{M}$. On the other hand, compound 22, with a methoxyl group in the para position, displayed the lowest $\mathrm{MIC}_{90}$ value among the phenyl quinoxaline series. Nevertheless, we could not observe a clear and accurate structure-activity relationship with regard to the electronic properties of the substituents.
For compounds $\mathbf{2 5}$ and 26, the isosteric replacement of the phenyl group by a furan or thiophen ring led to a significant increase in the antitubercular activity. Compounds 25 and 26 exhibited $\mathrm{MIC}_{90}$ values of 5.2 and $12.1 \mu \mathrm{M}$, respectively. Furthermore, we synthesized a quinoxaline derivative containing an $\mathrm{N}$-acylhydrazone subunit (28); the antitubercular activity of this compound decreased in comparison to that of the previous quinoxalines, exhibiting an $\mathrm{MIC}_{90}$ value of $39.7 \mu \mathrm{M}$.

Further in Vitro Biological Profiling of Selected Compounds. We evaluated the cytotoxicity of the final compounds against the MRC-5 cell line. This cell line is derived from healthy human lung fibroblasts and is widely utilized for the phenotypic screening of antitubercular drugs. ${ }^{69-71}$

The data obtained in the cytotoxicity studies of the amidefuroxan series $(4 a-c)$ indicated a high selectivity of these compounds against $M t b$. All three regioisomers exhibited high $\mathrm{IC}_{50}$ values $(>854.0 \mu \mathrm{M})$, thereby leading to high SI values, which ranged from 2033 to 3205 (Table 1).

Regarding the cytotoxicity studies of the benzofuroxan series, we observed $\mathrm{IC}_{50}$ values ranging from 25 to $841 \mu \mathrm{M}$ against the MRC-5 cell line. The most active benzofuroxan derivative (8) presented an $\mathrm{IC}_{50}$ value of $519 \mu \mathrm{M}$; however, compound 17 was found to be less cytotoxic among the benzofuroxan series with an $\mathrm{IC}_{50}$ value of $841 \mu \mathrm{M}$. Compounds 11-14 did not display promising antitubercular activity $\left(\mathrm{MIC}_{90}>62 \mu \mathrm{M}\right)$ and consequently were excluded from the cytotoxicity studies. Rather, compound $\mathbf{8}$ was selected for further experiments as it possessed the highest potency against $M t b$ and the lowest cytotoxicity.

Compounds from the quinoxaline series were significantly more cytotoxic against MRC-5 cells, with $\mathrm{IC}_{50}$ values ranging 
Table 2. MIC Determinations with Compound 8 against M. tuberculosis H37Rv (ATCC 27294) under Three Different Conditions

\begin{tabular}{|c|c|c|c|c|c|c|c|c|}
\hline \multirow[b]{2}{*}{ compound } & \multicolumn{2}{|c|}{ normal $^{a}$} & \multicolumn{2}{|c|}{ acidic $\mathrm{pH}^{b}$} & \multicolumn{2}{|c|}{$\mathrm{FBS}^{c}$} & \multicolumn{2}{|c|}{$\mathrm{BSA}^{d}$} \\
\hline & $\operatorname{MIC}(\mu \mathrm{M})$ & SD & $\operatorname{MIC}(\mu \mathrm{M})$ & SD & $\operatorname{MIC}(\mu \mathrm{M})$ & SD & $\operatorname{MIC}(\mu \mathrm{M})$ & SD \\
\hline 8 & 5.47 & 1.01 & 3.41 & 1.52 & 11.79 & 0.93 & 9.81 & 1.21 \\
\hline rifampicin & 0.05 & 0.03 & 0.02 & 0.02 & 0.10 & 0.08 & 0.10 & 0.03 \\
\hline
\end{tabular}

${ }^{a}$ Normal: normal pH media (6.8). ${ }^{b}$ Acidic $\mathrm{pH}$ : media $\mathrm{pH}$ adjusted to $6.0 .{ }^{c} \mathrm{FBS}: 10 \%$ fetal bovine serum. ${ }^{d}$ BSA: $4 \%$ bovine serum albumin.

Table 3. Antitubercular Activity of N-Oxide-Containing Heterocycles against M. tuberculosis Monoresistant Strains

\begin{tabular}{|c|c|c|c|c|c|c|c|}
\hline \multirow[b]{2}{*}{ class } & \multirow[b]{2}{*}{ compound } & \multicolumn{6}{|c|}{$\operatorname{MIC}(\mu \mathrm{M})$} \\
\hline & & $\mathrm{INHr}^{a}$ & $\operatorname{RMPr}^{a}$ & $\mathrm{MOXr}^{a}$ & $\mathrm{BDQr}^{a}$ & CAPr $^{a}$ & $\mathrm{SMr}^{a}$ \\
\hline \multirow[t]{3}{*}{ furoxan } & $4 a$ & $>261.71$ & 0.44 & 0.81 & 0.81 & $>261.71$ & 27.4 \\
\hline & $4 b$ & $>261.71$ & 2.31 & 1.22 & 2.56 & $>261.71$ & $>261.71$ \\
\hline & $4 c$ & $>261.71$ & 1.99 & 0.66 & 6.38 & $>261.71$ & $>261.71$ \\
\hline benzofuroxan & 8 & 8.59 & 3.78 & 5.72 & 1.20 & 15.25 & 16.98 \\
\hline \multirow[t]{6}{*}{ standard drugs } & RIF & 0.01 & $>1.00$ & 0.10 & 0.04 & 0.21 & 0.03 \\
\hline & $\mathrm{INH}$ & $>5.0$ & 0.35 & 0.28 & 0.23 & $>5.00$ & $>5.00$ \\
\hline & MOX & 0.23 & 0.12 & $>8.00$ & 0.26 & 0.35 & 0.36 \\
\hline & BDQ & 0.01 & 0.01 & 0.06 & 1.70 & 0.06 & 0.06 \\
\hline & CAP & - & - & - & - & 60.46 & 1.72 \\
\hline & SM & - & - & - & - & 2.55 & $>100$ \\
\hline
\end{tabular}

${ }^{a} \mathrm{INHr}$, isoniazid resistant; RMPr, rifampicin resistant; MOXr, moxifloxacin resistant; ,BDQr, bedaquiline resistant; CAPr, capreomycin resistant; and $\mathrm{SMr}$, streptomycin resistant. Dash $(-)$ indicates not determined.

from 13 to $67 \mu \mathrm{M}$, thereby resulting in low SI $(<6.8)$ values and making them less attractive candidates as antitubercular agents. ${ }^{56}$

The data obtained from $\mathrm{MIC}_{90}$ values under different conditions (Table 2) indicated no significant differences between $\mathrm{MIC}_{90}$ values under normal and others conditions. These conditions included (a) adjusting the $\mathrm{pH}$ of the culture medium to 6.0, (b) including 4\% BSA, and (c) supplementing with 10\% FBS.

The activity of antimicrobials is classified as containing narrow, intermediate, or broad spectrum. Tuberculosis is a chronic infection, the treatment of which requires a drug with a narrow spectrum, such as INH. All amide-furoxan and benzofuroxan $(8,11,14$, and 17) derivatives were checked against $S$. aureus, E. coli, and C. albicans. No antimicrobial activity was detected up to a maximum concentration of $200 \mu \mathrm{M}$.

In terms of cross-resistance, compound 8 displayed equipotent activity (<2-fold change in $\mathrm{MIC}_{90}$ ) against all drug-sensitive and monoresistant strains of $M t b$ tested, suggesting a novel MOA or inhibition of a shared target containing a distinct binding site by the compound (Table 3 ). In contrast, the amide-furoxan series $(4 \mathbf{a}-\mathbf{c})$ was inactive against half of the monoresistant strains tested and therefore was not selected for further studies.

We utilized J774A.1, a macrophage cell line, to study the intracellular inhibition of $M t b$ using the drugs under analysis. We observed that compound $\mathbf{8}$ exhibited high intracellular inhibition at all concentrations tested (around 90\%). However, similar to RMP, we could not verify the dose-dependent inhibition at different concentrations (Figure 2). In time-kill kinetic experiments, compound $\mathbf{8}$ was observed to be bactericidal with an early bactericidal effect. Noteworthy, compound 8 could sterilize the cultures after $48 \mathrm{~h}$ of exposure (about of $6.7 \log _{10}$; Figure 3).

Preliminary ADMT Studies of Compound 8. On the basis of the promising biological results described above for compound $\mathbf{8}$, we conducted stability and ADMT studies to assess its drug-like properties, such as absorption, distribution, and metabolism. To analyze the chemical stability of the compound, we conducted an in vitro assay under two $\mathrm{pH}$ conditions

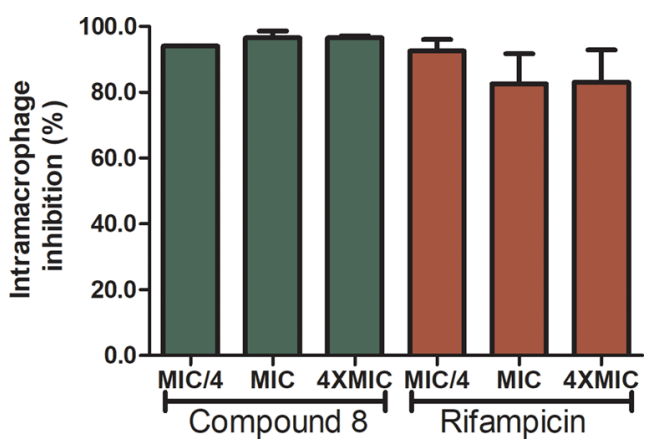

Figure 2. Intramacrophage activity of compound $\mathbf{8}$ and RMP after infection of J774A.1 macrophages with M. tuberculosis H37Rv (ATCC 27294). The percentage of inhibition was determined as the mean of three independent assays. The concentrations of the compounds were as follows: compound 8: $23.86 \mu \mathrm{g} / \mathrm{mL}$ (4× MIC), $5.84 \mu \mathrm{g} / \mathrm{mL}$ (MIC), and $1.46 \mu \mathrm{g} / \mathrm{mL}$ (MIC/4); positive control (RMP): $0.064 \mu \mathrm{g} / \mathrm{mL}$ (4× MIC), $0.016 \mu \mathrm{g} / \mathrm{mL}$ (MIC), and $0.04 \mu \mathrm{g} / \mathrm{mL}$ (MIC/4). Bars: mean $\pm \mathrm{SD}$.

(5.5 and 7.4) to mimic the environment of a macrophage phago-

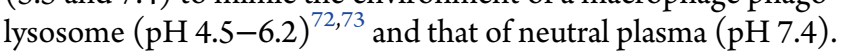
At $\mathrm{pH} 5.5$ and 7.4, compound 8 exhibited good stability (Figure 4); however, a reduction of $20 \%$ was detected at both $\mathrm{pH}$ values after $10 \mathrm{~h}$. Interestingly, the concentration of compound 8 was 67 and $75 \%$ at $\mathrm{pH} 5.5$ and 7.4, respectively, after $24 \mathrm{~h}$. The degradation rate of compound 8 was calculated by HPLC-UV; however, we did not characterize the degradation products. These results indicated that compound $\mathbf{8}$ exhibited high stability in the physiological $\mathrm{pH}$ range in the target areas of bacteria, namely, blood and phagolysosome.

The in vitro ADMT properties of compound $\mathbf{8}$ are listed in Table 4. The benzofuroxan derivative demonstrated a $46.5 \%$ unbound fraction when an in vitro plasma protein binding assay was conducted. The findings from the study of compound 8 on the inhibition of cytochrome $\mathrm{P} 450$ isoforms indicated no potential for inhibition, presenting $\mathrm{IC}_{50}$ values greater than $15.0 \mu \mathrm{M}$ 


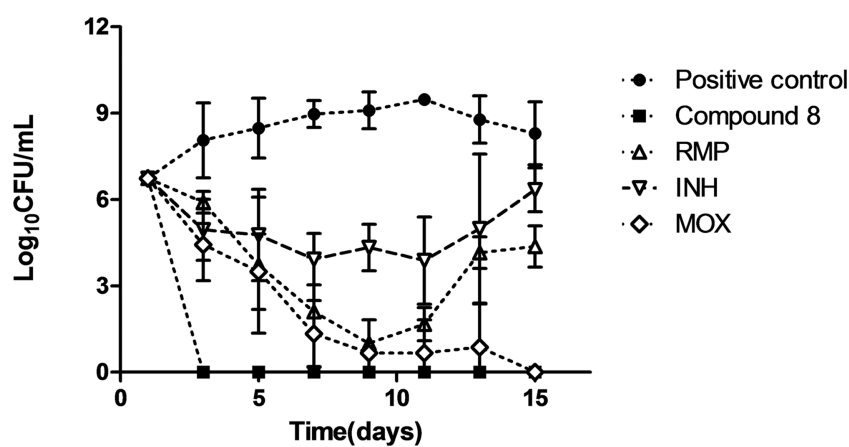

Figure 3. Time-kill curves of compound 8, rifampicin, isoniazid, and moxifloxacin. Results are in $\log _{10} \mathrm{CFU} / \mathrm{mL}$ of $M$. tuberculosis $\mathrm{H} 37 \mathrm{Rv}$ (ATCC 27294) according to time (days). The CFU count was determined as the mean of three independent assays. The concentrations of the compounds were $0.72 \mu \mathrm{M}$ for INH, $0.01 \mu \mathrm{M}$ for RMP, $0.88 \mu \mathrm{M}$ for MOX, and $41.24 \mu \mathrm{M}$ for compound 8 . Bars: mean $\pm \mathrm{SD}$.

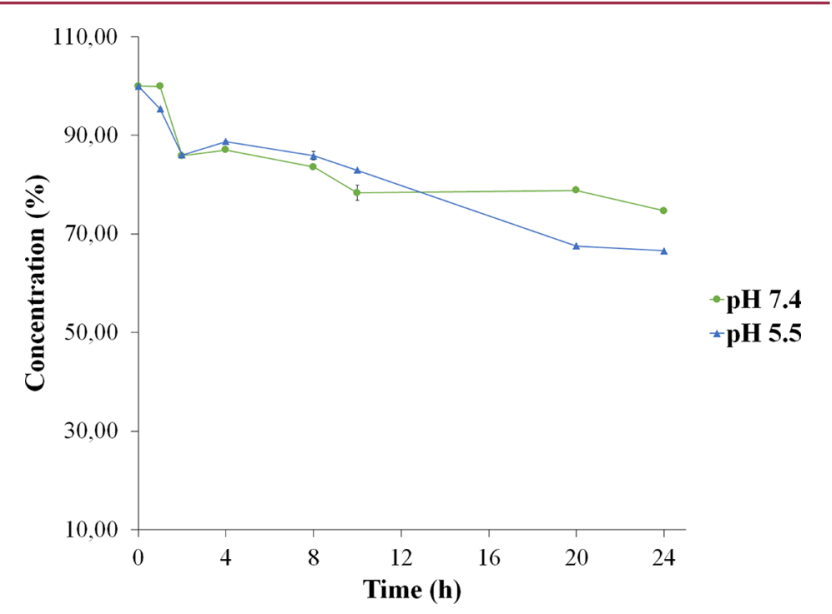

Figure 4. In vitro chemical stability. Hydrolytic profile of compound 8 in buffer ( $\mathrm{pH} 5.5$ and 7.4) (data are the mean \pm SEM expressed as a percentage).

\section{Table 4. In Vitro ADMT Data for Compound 8}

\begin{tabular}{ll}
\multicolumn{1}{c}{ assay } & compound 8 \\
human plasma protein binding (\% free) & 46.5 \\
Caco-2 permeability & \\
A-B $P_{\text {app }}{ }^{a}(\mathrm{~cm} / \mathrm{s})$ & $5.67 \times 10^{-6}$ \\
B $-\mathrm{A} P_{\text {app }}{ }^{a}(\mathrm{~cm} / \mathrm{s})$ & $3.90 \times 10^{-6}$ \\
CYP inhibition IC $50(\mu \mathrm{M})$ & $>20$ \\
CYP2B6 & $>20$ \\
CYP2C 8 & 15.3 \\
CYP2C19 & $>20$ \\
CYP3A4 & 16 \\
HepG2 IC 50 ( $\mu$ M) & \\
${ }^{a} P_{\text {app }}$ is the apparent permeability rate coefficient. & \\
\hline
\end{tabular}

against all isoforms tested. The studies in the Caco- 2 cell line demonstrated a good permeability profile. The cytotoxicity study conducted in HepG2 cells reported an $\mathrm{IC}_{50}$ of $16.0 \mu \mathrm{M}$ and an SI of 14.5. We also performed the micronucleus assay using mouse peripheral blood reticulocytes for compound 8 to evaluate its intrinsic mutagenic activity. The results indicated that compound 8 was not genotoxic at any concentration tested (Figure 5).

Tolerability, Oral Bioavailability, and Efficacy of Compound $\mathbf{8}$ in Mice. In vivo oral bioavailability, toxicology, infection, and treatment studies were performed to ensure the safety and efficacy of compound $\mathbf{8}$.

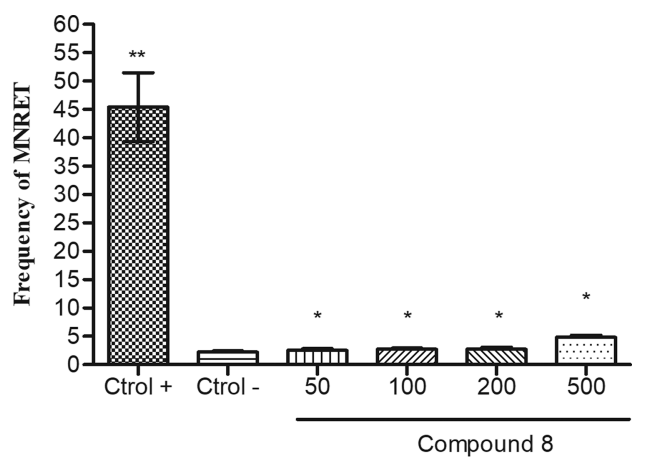

Treatments (mg/kg body weight)

Figure 5. Average frequency of micronucleated reticulocytes (MNRET) and standard deviation of 1000 cells obtained from mice treated with the positive control cyclophosphamide $(50 \mathrm{mg} / \mathrm{kg}), \mathrm{CMC} /$ Tween (negative control), or compound $8(50,100,200$, and $500 \mathrm{mg} / \mathrm{kg}$ body weight). $*_{p}<0.05$ (compared to negative control); $*^{*} p<0.05$ (compared to the negative control and compound 8 ).

For toxicology studies, mice were monitored daily for 10 days, receiving one daily oral dose (by gavage, $200 \mathrm{mg} / \mathrm{kg}$ body weight), and their behavior parameters (hippocratic screening) were evaluated. No significant variation in the behavior of mice was observed during the period of 10 days. Changes in the weight of organs (heart, lungs, spleen, kidneys, and liver) were evaluated using analysis of variance (ANOVA) and Dunnett's test, establishing a $p$-value $<0.05$ as the significant level. No statistically significant difference was observed between the drugtreated and control groups. To probe for potential liver damage, the levels of liver transaminases were checked in the plasma and indicated no significant differences for alanine aminotransferase (Figure 6a), aspartate aminotransferase (Figure 6b), and alkaline phosphatase (Figure 6c) between the treated and control groups. Similarly, we evaluated the levels of urea in blood samples to assess potential changes in kidney function. Here, a significant difference was observed for the group treated with RMP-ME when compared to the control group (Figure 6d). The study of the oral bioavailability of compound $\mathbf{8}$ displayed an inhibition of $M t b$ growth in mouse plasma (Table 5).

The histology of the liver (Figure 7) and kidneys (Figure 8) revealed that the morphology of these tissues was the same in all groups, implying that no gross abnormalities were caused by the treatments.

The efficacy of compound $\mathbf{8}$ was analyzed by infecting the mice with $M t b$ strain $\mathrm{H} 37 \mathrm{Rv}$ followed by subjecting the infected animals to the treatment with compound $\mathbf{8}$ or vehicle. The homogenized lung samples were plated at dilutions of 1:100 to 1:10000, at which no growth of $M t b$ colonies was observed. Therefore, the homogenized lung samples were reinoculated on agar plates in undiluted form and at 1:10 dilution; however, again, no colonies were observed (Figure 9). Control experiments with vehicle, RPM, and RPM-CE behaved as expected (Figure 9).

Mode of Action Studies. Although the antitubercular activity of benzofuroxan derivative $\mathbf{8}$ was originally attributed to its potential to generate and release nitric oxide (NO), we no longer believe this to be the case because the compound could not result in the release of NO in the Griess assay (a chemical test to analyze nitrite ions in solution; data not shown). An alternative mechanism was proposed as mentioned below.

Microarray analysis of $M t b$ treated with compound 8 or vehicle control revealed a significant upregulation in the majority of ribosomal genes as well as all genes encoding subunits of ATP 

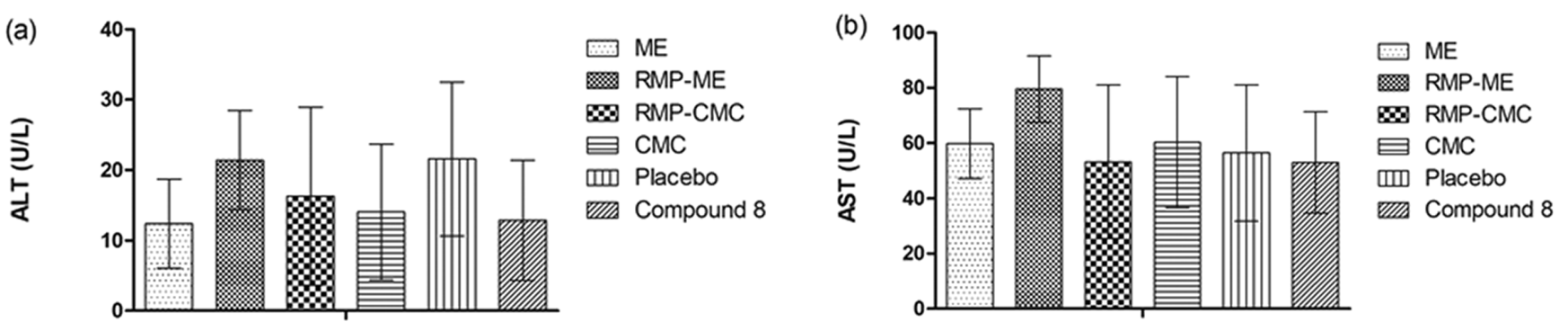

(c)

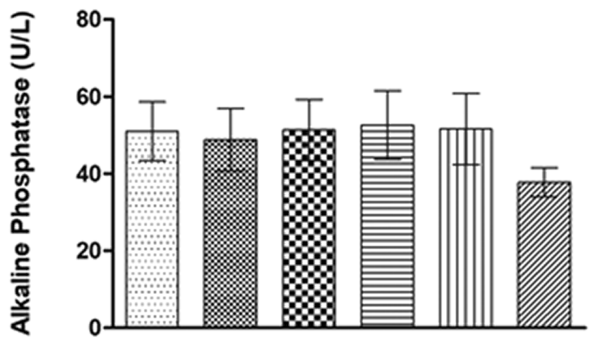

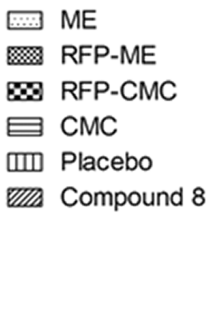

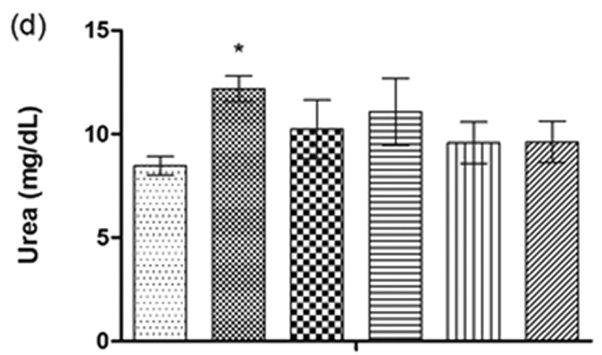

$2.2 \mathrm{ME}$

RMP-ME

80 RMP-CMC

$\sqsupseteq \mathrm{CMC}$

피 Placebo

שIt Compound 8

Figure 6. Alanine aminotransferase (a), aspartate aminotransferase (b), and alkaline phosphatase enzyme activity determinations (c) and urea quantification (d) in the plasma of BALB/c mice. Each compound was administered at a daily oral dose (gavage) at a concentration of $200 \mathrm{mg} / \mathrm{kg}$ body weight ( $n=4$ animals/group); RMP was at a concentration of $20 \mathrm{mg} / \mathrm{kg}$. Statistical analysis was performed using GraphPad Prism, version 5.01 , through ANOVA and Dunnett's test, establishing $P<0.05$ as the significance level. Bars: SD.

Table 5. Plasma Levels of Compound 8, RMP-ME, and RMP-CMC Following a Single Oral Administration ${ }^{a}$

\begin{tabular}{|c|c|c|c|c|c|c|c|c|c|c|}
\hline \multirow[b]{3}{*}{ compound } & \multirow{3}{*}{$\begin{array}{c}\text { standard }^{b} \\
\text { MIC }(\mu \mathrm{g} / \mathrm{mL}) \\
\text { predetermined }\end{array}$} & \multirow[b]{3}{*}{$\begin{array}{c}\text { drug dose } \\
(\mathrm{mg} / \mathrm{kg} / \text { body })\end{array}$} & \multicolumn{8}{|c|}{ mouse data ${ }^{c}$} \\
\hline & & & \multicolumn{2}{|c|}{$0.3 \mathrm{~h}$} & \multicolumn{2}{|c|}{$1 \mathrm{~h}$} & \multicolumn{2}{|c|}{$2 \mathrm{~h}$} & \multicolumn{2}{|c|}{$4 \mathrm{~h}$} \\
\hline & & & $\begin{array}{c}\text { inhibition } \\
(\%)\end{array}$ & $\begin{array}{l}\text { estimate } \\
(\mu \mathrm{g} / \mathrm{mL})\end{array}$ & $\begin{array}{c}\text { inhibition } \\
(\%)\end{array}$ & $\begin{array}{l}\text { estimate } \\
(\mu \mathrm{g} / \mathrm{mL})\end{array}$ & $\begin{array}{c}\text { inhibition } \\
(\%)\end{array}$ & $\begin{array}{l}\text { estimate } \\
(\mu \mathrm{g} / \mathrm{mL})\end{array}$ & $\begin{array}{c}\text { inhibition } \\
(\%)\end{array}$ & $\begin{array}{l}\text { estimate } \\
(\mu \mathrm{g} / \mathrm{mL})\end{array}$ \\
\hline compound (8)-ME & 5.84 & 300 & 65.67 & 42.61 & 79.00 & 51.26 & 76.00 & 49.31 & 51.33 & 33.30 \\
\hline RMP-ME & 0.015 & 20 & 66.33 & 0.11 & 63.00 & 0.31 & 76.33 & 0.37 & 91.00 & 0.15 \\
\hline RMP-CMC & 0.015 & 20 & 73.67 & 0.11 & 84.00 & 0.14 & 62.27 & 0.10 & 68.00 & 0.11 \\
\hline
\end{tabular}

${ }^{a}$ Experiments were carried out in BALB/c mice. ${ }^{b}$ Predetermined by the Resazurin microtiter assay (REMA) in vitro. ${ }^{c}$ Determined using mouse plasma by REMA in vitro; estimates in plasma are given.
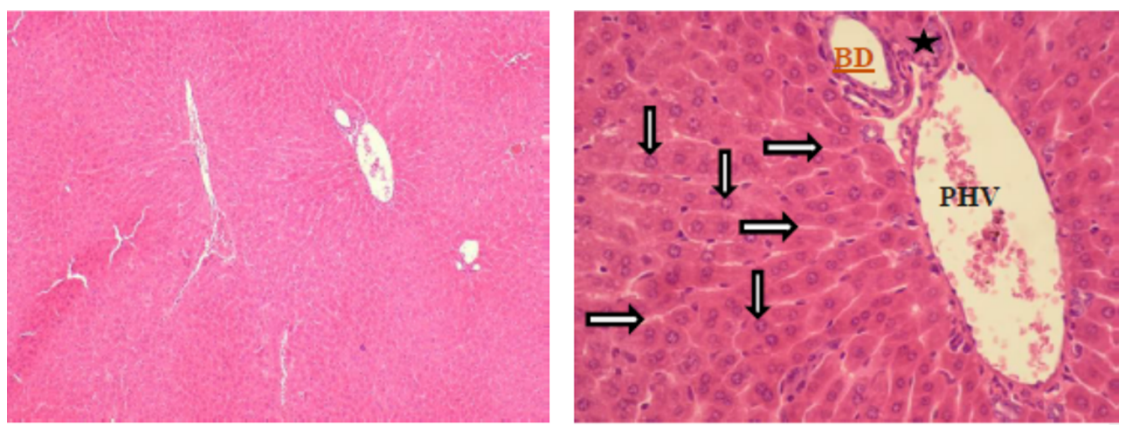

Figure 7. Histological section of liver stained with H\&E from the group treated with compound 8. Histological sections stained with H\&E showed, in general, the presence of hepatocytes with polyhedral morphology, grouped in strings separated by sinusoids, forming well-defined hepatic lobes. The sinusoids, characterized as wall capillaries coated by typical endothelial cells, had some Kupffer cells. In each border of the hepatic lobe there was the presence of well-organized structures called portal spaces, which are characterized mainly by the presence of a portal hepatic vein (PHV), arteriole (A), and bile duct (BD). This set was surrounded by a layer of intact and continuous connective tissue, which appeared to be cut off by channels that discharged blood into the sinusoids, which flow into the central lobular vein.

synthase (Figure 10 and Table S1). This included EF-G, which induces GTP-dependent translocation of nascent peptide chains from the $\mathrm{A}$ - to the $\mathrm{P}$-site in the ribosome, and EF-Tu, which promotes GTP-dependent binding of aminoacylated tRNAs to the A-site in ribosomes. No upregulation of heat shock proteins was observed; in fact, a downregulation of $h s p, h t r A$, and $h s p R$ was demonstrated (Table S1). Similarly, upregulation of ribosomal proteins was observed upon treatment of $M t b$ with inhibitors of protein synthesis. Our data indicated an upregulation of a large number of operons as well as single genes encoding ribosomal proteins, which in turn suggested that compound 8 could affect protein synthesis by inhibiting the ribosome. Boshoff and co-workers ${ }^{65}$ divided protein synthesis inhibitors into two classes on the basis of their effect on the expression of heat shock 

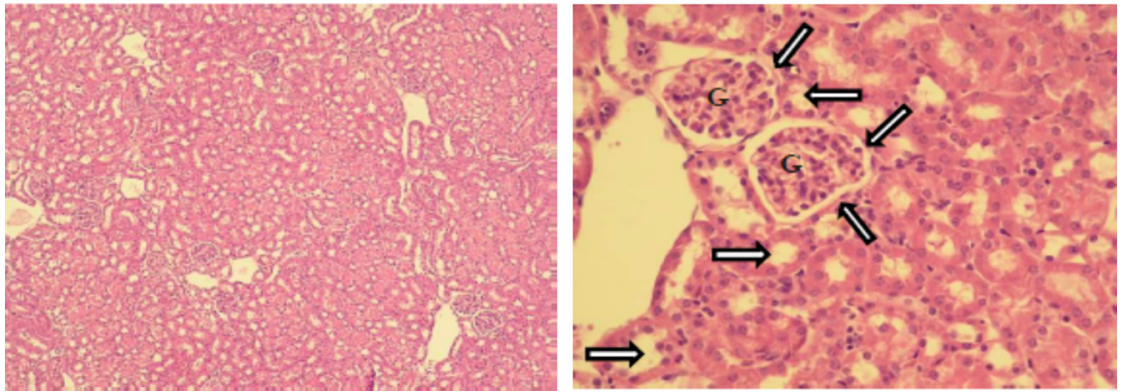

Figure 8. Histological section of kidneys stained with H\&E from the group treated with compound 8. Histological sections stained with H\&E generally exhibited morphologically normal, well- functional units of the kidney. Each nephron had the Malpighi corpuscle, characterized by the following structures: (1) Bowman's capsule, formed by simple pavement epithelium, and (2) glomerulus (G), characterized by a set of capillaries of the fenestrated type. Near the Malpighi corpuscle it was possible to observe proximal convoluted tubules formed by a simple layer of high cuboidal epithelial cells, which have brush edges facing the lumen of the tubules. Also adjacent to the Malpighi corpuscles were distal tubules formed by low cuboidal cells.

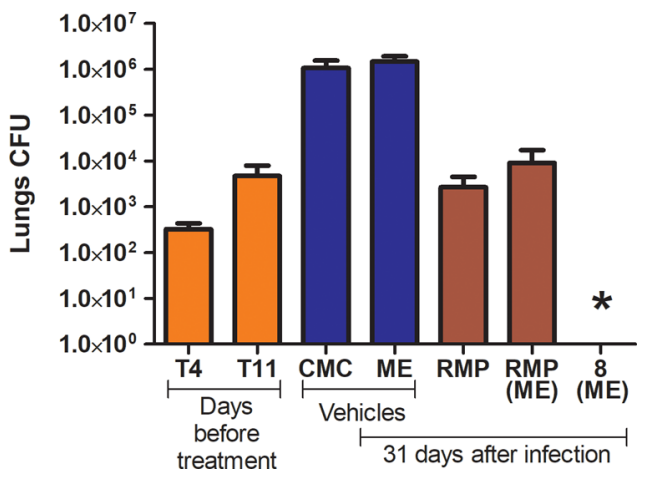

Figure 9. Efficacy of compound 8 in microemulsion and controls administrated once daily by oral gavage of a $200 \mu \mathrm{L}$ suspension. Efficacy of $200 \mathrm{mg} / \mathrm{kg}$ compound 8 against acute TB in mice. Female $20 \mathrm{~g}$ $\mathrm{BALB} / \mathrm{c}$ mice were infected by aerosol with a low dose $\left(5 \times 10^{6} \mathrm{CFU} / \mathrm{mL}\right)$ of $M$. tuberculosis Erdman. The start of treatment commenced at 10 days postinfection and terminated at 29 days postinfection. Dosages were obtained by once-daily dosing by oral gavage. Groups of 7 mice were dosed for 5 consecutive days each week. CFU were determined after a 3 day washout period at day 31 postinfection. Both lungs were homogenized and diluted in Hanks' balanced salt solution (HBSS)Tween, and aliquots were plated on Middlebrook $7 \mathrm{H} 11$ medium. Bars: SD. * indicates the effect of sterilization.

proteins (either no effect or upregulation). Compound 8 did not increase the abundance of transcripts encoding heat shock proteins and, in fact, decreased the levels of three transcripts ( $h s p$, $h t r A$, and $h s p R)$. The results of this study of the inhibition of protein synthesis indicated that compound 8 behaves more like an inhibitor of translation initiation, such as tetracyclines, rather than an inhibitor of protein synthesis that leads to mistranslation, such as aminoglycosides. Further studies are required to define the exact MOA of compound $\mathbf{8}$, including its binding site and inhibition of the $M t b$ ribosome, ATP synthase, or other targets.

\section{CONCLUSIONS}

Twenty-two new N-oxide-containing compounds were synthesized followed by in vitro and in vivo evaluation of their antitubercular activity against $M t b$. The amide-furoxan series $(4 \mathbf{a}-\mathbf{c})$ was observed to be the most promising compounds, with $\mathrm{MIC}_{90}$ values around $0.40 \mu \mathrm{M}$ against actively replicating $M t b$ and SI values ranging from 2033.3 to 3204.7 . The benzofuroxan series (8-17) also presented promising antitubercular activity, especially compound 8 , which reported $\mathrm{MIC}_{90}$ values of 1.1 and $6.6 \mu \mathrm{M}$ against actively growing and nonreplicating $M t b$, respectively. Compound 8 also displayed high activity in a macrophage model of infection. In addition, in vivo studies employing a mouse model of infection demonstrated the sterilizing activity of compound 8 . No detectable $M t b$ was observed in the lungs of treated mice, whereas control mice displayed the expected number of CFUs. Altogether, these findings highlight benzofuroxan derivative 8 as a novel lead compound for designing an antitubercular drug that possesses sterilizing activity superior to that of rifampicin in a mouse model of infection.

\section{EXPERIMENTAL SECTION}

Chemistry. Melting points $(\mathrm{mp})$ were measured using an electrothermal melting point apparatus (SMP3; Bibby Stuart Scientific) or in a Mettler FP82+FP80 apparatus (Greifense, Switzerland). Infrared spectroscopy ( $\mathrm{KBr}$ disc) was performed on a FTIR-8300 Shimadzu or a Nicolet Nexu FTIR Thermo spectrometer, and the frequencies are expressed in $\mathrm{cm}^{-1}$. NMR spectra for ${ }^{1} \mathrm{H}$ and ${ }^{13} \mathrm{C}$ of all compounds were recorded on a Bruker Fourier spectrometer with a dual ${ }^{13} \mathrm{C} /{ }^{1} \mathrm{H}$ $(300 \mathrm{MHz})$ probe or a Bruker 400 Ultrashield ${ }^{13} \mathrm{C} /{ }^{1} \mathrm{H}(400 \mathrm{MHz})$ spectrometer using deuterated chloroform $\left(\mathrm{CDCl}_{3}\right)$ or dimethyl sulfoxide (DMSO- $d_{6}$ ) as solvent; the chemical shifts are expressed in parts per million ( $\mathrm{ppm}$ ) relative to tetramethylsilane. The signal multiplicities are reported as singlet (s), doublet (d), doublet of doublets (dd), and multiplet $(\mathrm{m})$. Elemental microanalysis $(\mathrm{C}, \mathrm{H}$, and $\mathrm{N}$ ) was performed on a PerkinElmer model 2400 analyzer or a CHN-900 Elemental Analyzer (LECO, Tres Cantos, Spain), and the data were within $\pm 0.4 \%$ of theoretical values. HRMS $\left(\mathrm{ESI}^{+}\right)$data were acquired using a Bruker Maxis Impact quadrupole time-of-flight tandem mass spectrometer ( $\mathrm{Q}-\mathrm{TOF} \mathrm{MS} / \mathrm{MS}$ ), and the mass spectra values are reported as $m / z$. The compounds were purified on a chromatography column with silica gel ( 60 Å pore size, $35-75-\mu \mathrm{m}$ particle size), and the following solvents were used as the mobile phase: methanol, ethyl acetate, dichloromethane, hexane, and petroleum ether in a flow rate of approximately $20 \mathrm{~mL} / \mathrm{min}$. The reaction progress of all compounds was monitored by thin-layer chromatography (TLC), which was performed on $2.0 \times 6.0 \mathrm{~cm}^{2}$ aluminum sheets precoated with silica gel 60 (HF-254; Merck) to a thickness of $0.25 \mathrm{~mm}$ and revealed under UV light $(265 \mathrm{~nm})$. All compounds were analyzed by HPLC, and their purity was confirmed to be greater than $98.5 \%$. HPLC conditions: Shimadzu HPLC model CBM 20-A (Shimadzu) equipped with UV-vis detector (model SPD20A), quaternary pumping system mobile phase (model LC-20AT), solvent degasser (model DGU-20As), and an Agilent Eclipse XDB C-18 column $(250 \mathrm{~mm} \times 274,6 \mathrm{~mm} ; 5 \mu \mathrm{m})$. For HPLC, an isocratic flow was used [methanol/water $(75: 25)]$. Reagents and solvents were purchased from commercial suppliers. Compounds $3 a-c,{ }^{45-47} 7,{ }^{48} \mathbf{1 8}, 19$, and $28^{54}$ were prepared according to previously described methods.

General Procedure for the Synthesis of Compounds $4 a-c$ and 8-17. A solution of compound $3 \mathrm{a}-\mathrm{c}$ or $7(0.87 \mathrm{mmol})$ in $10 \mathrm{~mL}$ of ethanol and 3 drops of glacial acetic acid was stirred at room temperature for $20 \mathrm{~min}$. Next, the appropriate aromatic hydrazide $(0.106 \mathrm{~g}$, $0.87 \mathrm{mmol}$ ) was added, and the mixture was stirred for $12 \mathrm{~h}$. The solvent 
(a)

(b)

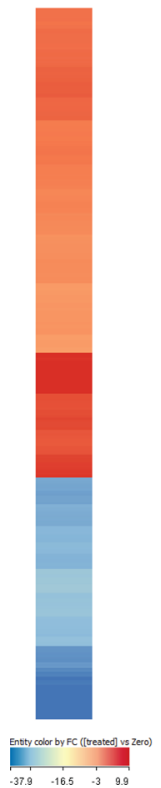

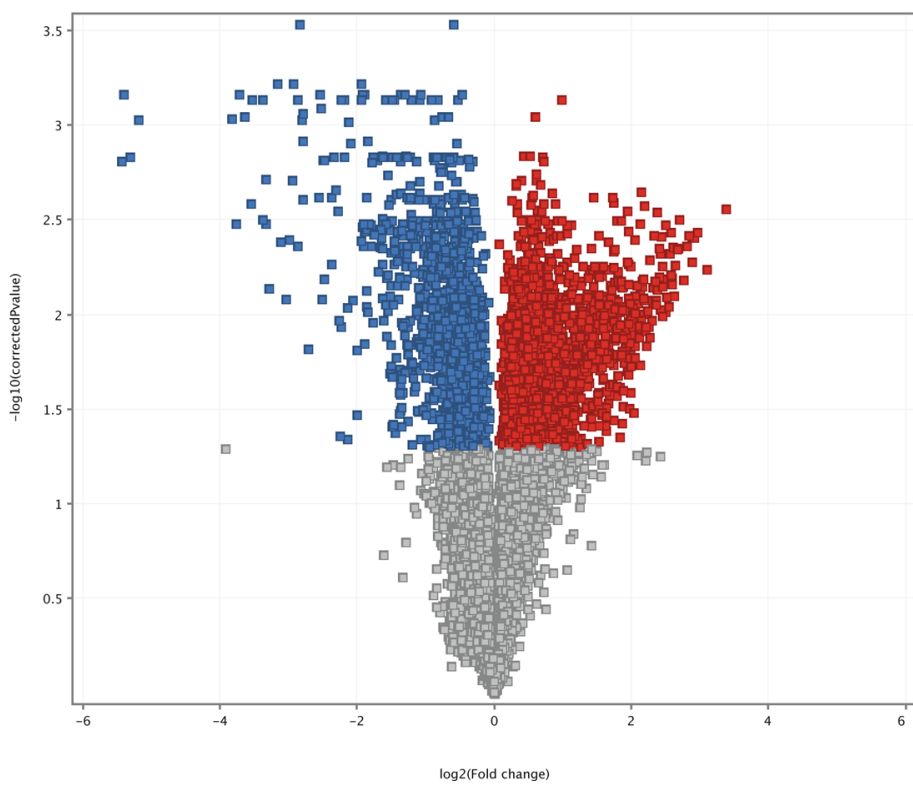

(c)

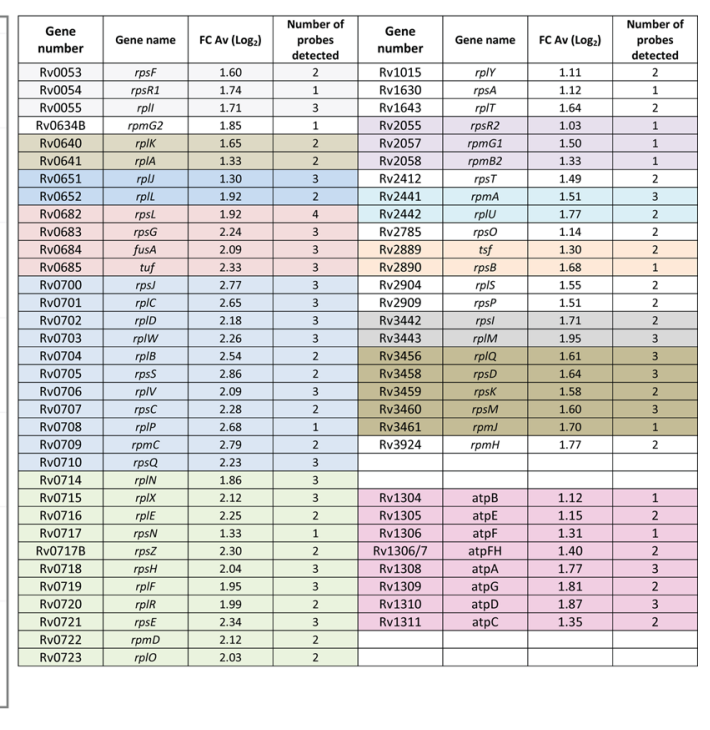

Figure 10. Gene expression after $4 \mathrm{~h}$ of exposure to compound 8 at $2 \times$ MIC by microarray. (a) Heatmap and (b) volcano plot, illustrating the effect of compound 8 versus vehicle on gene expression in M. tuberculosis H37Rv. (c) Table showing two examples of upregulated genes associated with the ribosome or ATP synthase.

was concentrated under reduced pressure, and ice was added to precipitate the desired products. If necessary, the samples were further purified by silica gel column chromatography using ethyl acetate/ methanol $(98: 2 \mathrm{v} / \mathrm{v})$ as eluent to give the appropriate compound $(\mathbf{4 a}-\mathrm{c}$ and $8-17)$ in variable yields.

(E)-3-Carbamoyl-4-((2-((2-isonicotinoylhydrazono)methyl)phenoxy)methyl)-1,2,5-oxadiazole 2-Oxide (4a). White powder; yield, 51\%; mp 226 to $229{ }^{\circ} \mathrm{C}$. IR $V_{\max }\left(\mathrm{cm}^{-1}\right.$; $\mathrm{KBr}$ pellets): 3433 ( $\mathrm{NH}_{2}$ amide), $3203(\mathrm{~N}-\mathrm{H}), 1669(\mathrm{C}=\mathrm{O}$ amide $), 1587(\mathrm{C}=\mathrm{N}$ imine $)$, 1456 (N-O furoxan), 1344 (C-N aromatic), 1145 (C-O ether). ${ }^{1} \mathrm{H}$ NMR $\left(300 \mathrm{MHz}, \mathrm{DMSO}-d_{6}, \delta \mathrm{ppm}\right) \delta: 12.10(1 \mathrm{H} ; \mathrm{s} ; \mathrm{N}-\mathrm{H}), 8.79(2 \mathrm{H}$; d), $8.51(1 \mathrm{H} ; \mathrm{s}), 7.91(1 \mathrm{H} ; \mathrm{dd}), 7.84(2 \mathrm{H} ; \mathrm{d}), 7.46(1 \mathrm{H} ; \mathrm{m}), 7.25(1 \mathrm{H}$; d), $7.11(1 \mathrm{H} ; \mathrm{t}), 5.54(2 \mathrm{H} ; \mathrm{s}) .{ }^{13} \mathrm{C}$ NMR $\left(75 \mathrm{MHz}, \mathrm{DMSO}-d_{6}, \delta \mathrm{ppm}\right)$ $\delta: 161.55,156.36,155.65,155.24,150.30,144.04,140.47,131.84$, $125.85,122.59,121.87,121.59,113.36,110.51$. Anal. Calcd (\%) for $\mathrm{C}_{16} \mathrm{H}_{12} \mathrm{~N}_{6} \mathrm{O}_{5}$ : C: 52.18; H: 3.28; N: 22.82. Found: C: 52.25; H: 3.29; $\mathrm{N}: 22.90$. HRMS: $m / z\left(\mathrm{ESI}^{+}\right)=405.0918[\mathrm{M}+\mathrm{Na}]^{+}$.

(E)-3-Carbamoyl-4-((3-((2-isonicotinoylhydrazono)methyl)phenoxy)methyl)-1,2,5-oxadiazole 2-Oxide (4b). White powder; yield, 59\%; mp 159 to $163{ }^{\circ} \mathrm{C}$. IR $V_{\max }\left(\mathrm{cm}^{-1} ; \mathrm{KBr}\right.$ pellets): 3439 ( $\mathrm{NH}_{2}$ amide), $3201(\mathrm{~N}-\mathrm{H}), 1712(\mathrm{C}=\mathrm{O}$ amide $), 1591$ ( $\mathrm{C}=\mathrm{N}$ imine $)$, 1485 (N-O furoxan), 1327 (C-N aromatic), 1147 (C-O ether). ${ }^{1} \mathrm{H}$ NMR (300 MHz, DMSO- $d_{6}, \delta$ ppm) $\delta: 12.09(1 \mathrm{H} ; \mathrm{s} ; \mathrm{N}-\mathrm{H}), 8.78(2 \mathrm{H}$; d), $8.46(1 \mathrm{H} ; \mathrm{s}), 7.81(3 \mathrm{H} ; \mathrm{d}), 7.41(3 \mathrm{H} ; \mathrm{m}), 5.48(2 \mathrm{H} ; \mathrm{s}) .{ }^{13} \mathrm{C}$ NMR $\left(75 \mathrm{MHz}, \mathrm{DMSO}-d_{6}, \delta \mathrm{ppm}\right) \delta: 156.96,150.22,147.97,147.44,142.63$, 140.97, 132.70, 127.87, 122.48, 113.82, 113.14, 109.30, 105.24, 102.74 . Anal. Calcd (\%) for $\mathrm{C}_{16} \mathrm{H}_{12} \mathrm{~N}_{6} \mathrm{O}_{5}$ : C: 52.18; $\mathrm{H}: 3.28 ; \mathrm{N}: 22.82$. Found: C: $52.27 ; \mathrm{H}: 3.29 ; \mathrm{N}: 22.90$. HRMS: $m / z\left(\mathrm{ESI}^{+}\right)=405.0922[\mathrm{M}+\mathrm{Na}]^{+}$.

(E)-3-Carbamoyl-4-((4-((2-isonicotinoylhydrazono)methyl)phenoxy)methyl)-1,2,5-oxadiazole 2-Oxide (4c). White powder; yield, 67\%; mp 235 to $239{ }^{\circ} \mathrm{C}$. IR $V_{\max }\left(\mathrm{cm}^{-1}\right.$; $\mathrm{KBr}$ pellets): $3.367\left(\mathrm{NH}_{2}\right.$ amide), $3255(\mathrm{~N}-\mathrm{H}), 1708(\mathrm{C}=\mathrm{O}$ amide $), 1612(\mathrm{C}=\mathrm{N}$ imine $), 1413$ ( $\mathrm{N}-\mathrm{O}$ furoxan ), 1255 (C-N aromatic), 1122 (C-O ether). ${ }^{1} \mathrm{H}$ NMR $\left(300 \mathrm{MHz}, \mathrm{DMSO}-d_{6}, \delta \mathrm{ppm}\right) \delta: 11.95(1 \mathrm{H} ; \mathrm{s} ; \mathrm{N}-\mathrm{H}), 8.77(2 \mathrm{H} ; \mathrm{d})$, $8.43(1 \mathrm{H} ; \mathrm{s}), 7.80(2 \mathrm{H} ; \mathrm{d}), 7.71(2 \mathrm{H} ; \mathrm{d}), 7.14(2 \mathrm{H} ; \mathrm{d}), 5.48(2 \mathrm{H} ; \mathrm{s}) .{ }^{13} \mathrm{C}$ NMR (75 MHz, DMSO- $d_{6}, \delta$ ppm) $\delta: 162.96,162.33,159.91,156.34$, $150.86,149.52$, 141.14, 129.65, 128.08, 122.14, 115.84, 111.05. Anal. Calcd (\%) for $\mathrm{C}_{16} \mathrm{H}_{12} \mathrm{~N}_{6} \mathrm{O}_{5}$ : C: 52.18; $\mathrm{H}: 3.28 ; \mathrm{N}: 22.82$. Found: C: 52.20; H: 3.28; N: 22.84. HRMS: $m / z\left(\mathrm{ESI}^{+}\right)=405.0913[\mathrm{M}+\mathrm{Na}]^{+}$.
(E)-6-((2-Isonicotinoylhydrazono ) methyl)benzo[c] $[1,2,5]$ oxadiazole 1-Oxide (8). Yellow powder; yield, $85 \%$; mp 230 to $232{ }^{\circ} \mathrm{C}$. IR $V_{\max }\left(\mathrm{cm}^{-1} ; \mathrm{KBr}\right.$ pellets $): 3324(\mathrm{~N}-\mathrm{H}), 3045\left(\mathrm{NH}_{2}\right.$ amide $), 1690$ (C=O amide), $1600(\mathrm{C}=\mathrm{N}$ imine $), 1409(\mathrm{~N}-\mathrm{O}$ furoxan $), 1273(\mathrm{C}-\mathrm{N}$ aromatic). ${ }^{1} \mathrm{H}$ NMR $\left(300 \mathrm{MHz}, \mathrm{DMSO}-d_{6}, \delta \mathrm{ppm}\right) \delta: 12.44(1 \mathrm{H} ; \mathrm{s})$, $8.80(2 \mathrm{H} ; \mathrm{d} ; J=5.7 \mathrm{~Hz}), 8.51(1 \mathrm{H} ; \mathrm{s}), 8.03(3 \mathrm{H} ; \mathrm{m}), 7.84(2 \mathrm{H} ; \mathrm{d} ; J=$ $6.0 \mathrm{~Hz}) .{ }^{13} \mathrm{C}$ NMR $\left(75 \mathrm{MHz}, \mathrm{DMSO}-d_{6}, \delta \mathrm{ppm}\right) \delta: 162.4,150.6,146.6$, 140.2, 133.7, 130.8, 130.4, 130.1, 129.4, 121.8, 114.3. Anal. Calcd (\%) for $\mathrm{C}_{13} \mathrm{H}_{9} \mathrm{~N}_{5} \mathrm{O}_{3}$ : C: $55.13 ; \mathrm{H}: 3.20 ; \mathrm{N}: 24.73$. Found: C: 55.22; H: 3.21; $\mathrm{N}: 24.78$. HRMS: $m / z\left(\mathrm{ESI}^{+}\right)=306.0602[\mathrm{M}+\mathrm{Na}]^{+}$.

(E)-6-((2-Benzoylhydrazono)methyl)benzo[c][1,2,5]oxadiazole 1-Oxide (9). Yellow powder; yield, $80 \%$; mp 220 to $221^{\circ} \mathrm{C}$. IR $V_{\max }\left(\mathrm{cm}^{-1}\right.$; $\mathrm{KBr}$ pellets): $3389(\mathrm{~N}-\mathrm{H}), 3041\left(\mathrm{NH}_{2}\right.$ amide $), 1641$ ( $\mathrm{C}=\mathrm{O}$ amide), $1533(\mathrm{C}=\mathrm{N}$ imine $), 1487$ (N-O furoxan), $1300(\mathrm{C}-\mathrm{N}$ aromatic $) .{ }^{1} \mathrm{H}$ $\operatorname{NMR}\left(300 \mathrm{MHz}, \mathrm{DMSO}-d_{6}, \delta \mathrm{ppm}\right) \delta: 12.24(1 \mathrm{H} ; \mathrm{s}), 8.52(1 \mathrm{H} ; \mathrm{s}), 7.94$ $(5 \mathrm{H} ; \mathrm{m}), 7.58(3 \mathrm{H} ; \mathrm{m}) .{ }^{13} \mathrm{C}$ NMR $\left(75 \mathrm{MHz}, \mathrm{DMSO}-d_{6}, \delta \mathrm{ppm}\right) \delta$ : 163.4, 145.0, 132.9, 132.1, 128.5, 127.8, 118.4, 113.5. Anal. Calcd (\%) for $\mathrm{C}_{14} \mathrm{H}_{10} \mathrm{~N}_{4} \mathrm{O}_{3}:$ C: $59.57 ; \mathrm{H}: 3.57 ; \mathrm{N}: 19.85$. Found: C: $59.65 ; \mathrm{H}: 3.56 ; \mathrm{N}$ : 19.88 .

(E)-6-((2-(4-(tert-Butyl)benzoyl)hydrazono)methyl)benzo[c]$[1,2,5]$ oxadiazole 1-Oxide (10). Yellow powder; yield, $89 \%$; $\mathrm{mp} 189$ to $191^{\circ} \mathrm{C}$. IR $V_{\max }\left(\mathrm{cm}^{-1}\right.$; $\mathrm{KBr}$ pellets $): 3341(\mathrm{~N}-\mathrm{H}), 3068\left(\mathrm{NH}_{2}\right.$ amide $)$, $1659(\mathrm{C}=\mathrm{O}$ amide $), 1532(\mathrm{C}=\mathrm{N}$ imine $), 1486(\mathrm{~N}-\mathrm{O}$ furoxan $), 1287$ (C-N aromatic). ${ }^{1} \mathrm{H}$ NMR $\left(300 \mathrm{MHz}, \mathrm{DMSO}-d_{6}, \delta \mathrm{ppm}\right) \delta: 12.16(1 \mathrm{H} ; \mathrm{s})$, $8.51(1 \mathrm{H} ; \mathrm{s}), 7.93(4 \mathrm{H} ; \mathrm{m}), 7.56(3 \mathrm{H} ; \mathrm{d} ; J=8.4 \mathrm{~Hz}), 1.32(9 \mathrm{H} ; \mathrm{s}) .{ }^{13} \mathrm{C}$ NMR (75 MHz, DMSO- $d_{6}, \delta$ ppm) $\delta: 160.3,155.0,144.7,130.2,127.7$, 125.3, 118.3, 113.3, 56.0, 34.8, 30.9. Anal. Calcd (\%) for $\mathrm{C}_{18} \mathrm{H}_{18} \mathrm{~N}_{4} \mathrm{O}_{3}$ : C: 63.89; H: 5.36; N: 16.56. Found: C: 63.95; H: 5.37; N: 16.59 .

(E)-6-((2-(4-Nitrobenzoyl)hydrazono)methyl)benzo[c][1,2,5]oxadiazole 1-Oxide (11). Yellow powder; yield, $78 \%$; mp 261 to $262^{\circ} \mathrm{C}$. IR $V_{\max }\left(\mathrm{cm}^{-1} ; \mathrm{KBr}\right.$ pellets $): 3373(\mathrm{~N}-\mathrm{H}), 3073\left(\mathrm{NH}_{2}\right.$ amide $)$, $1673(\mathrm{C}=\mathrm{O}$ amide $), 1525$ ( $\mathrm{C}=\mathrm{N}$ imine $), 1400(\mathrm{~N}-\mathrm{O}$ furoxan $), 1357$ (C-N aromatic). ${ }^{1} \mathrm{H}$ NMR $\left(300 \mathrm{MHz}, \mathrm{DMSO}-d_{6}, \delta \mathrm{ppm}\right) \delta: 12.50(1 \mathrm{H} ; \mathrm{s})$, $8.52(1 \mathrm{H} ; \mathrm{s}), 8.39(2 \mathrm{H} ; \mathrm{d} ; J=8.8 \mathrm{~Hz}), 8.17(2 \mathrm{H} ; \mathrm{d} ; J=8.8 \mathrm{~Hz}), 7.95$ $(3 \mathrm{H} ; \mathrm{m}) .{ }^{13} \mathrm{C}$ NMR $\left(75 \mathrm{MHz}, \mathrm{DMSO}-d_{6}, \delta \mathrm{ppm}\right) \delta: 162.2,149.4,146.2$, 138.7, 129.4, 123.7. Anal. Calcd (\%) for $\mathrm{C}_{14} \mathrm{H}_{9} \mathrm{~N}_{5} \mathrm{O}_{5}$ : C: 51.38; $\mathrm{H}: 2.77$; $\mathrm{N}: 21.40$. Found: C: $51.41 ; \mathrm{H}: 2.77 ; \mathrm{N}: 21.42$.

(E)-6-((2-(2-Hydroxybenzoyl)hydrazono)methyl)benzo[c][1,2,5]oxadiazole 1-Oxide (12). Yellow powder; yield, $79 \%$; mp 240 to $241{ }^{\circ} \mathrm{C}$. IR $V_{\max }\left(\mathrm{cm}^{-1} ; \mathrm{KBr}\right.$ pellets $): 3573(\mathrm{O}-\mathrm{H}), 3332(\mathrm{~N}-\mathrm{H}), 3100$ 
( $\mathrm{NH}_{2}$ amide), 1638 ( $\mathrm{C}=\mathrm{O}$ amide), 1532 ( $\mathrm{C}=\mathrm{N}$ imine), $1484(\mathrm{~N}-\mathrm{O}$ furoxan), 1341 (C-N aromatic). ${ }^{1} \mathrm{H}$ NMR (300 MHz, DMSO- $d_{6}$, $\delta \mathrm{ppm}) \delta: 12.12(1 \mathrm{H} ; \mathrm{s}), 11.64(1 \mathrm{H} ; \mathrm{s}), 8.51(1 \mathrm{H} ; \mathrm{s}), 7.95(4 \mathrm{H} ; \mathrm{m}), 7.45$ $(1 \mathrm{H} ; \mathrm{t} ; J=7.5 \mathrm{~Hz}), 6.99(2 \mathrm{H} ; \mathrm{m}) .{ }^{13} \mathrm{C}$ NMR $\left(75 \mathrm{MHz}, \mathrm{DMSO}-d_{6}\right.$, $\delta \mathrm{ppm}) \delta: 164.8,158.7,145.7,134.0,129.0,119.1,118.4,117.3,116.3$, 113.7. Anal. Calcd (\%) for $\mathrm{C}_{14} \mathrm{H}_{10} \mathrm{~N}_{4} \mathrm{O}_{4}$ : C: 56.38; H: 3.38; N: 18.79 . Found: C: 56.41; H: 3.37; N: 18.80 .

(E)-6-((2-(3-Hydroxybenzoyl)hydrazono)methyl)benzo[c][1,2,5]oxadiazole 1-Oxide (13). Yellow powder; yield, $81 \%$; mp 265 to $266^{\circ} \mathrm{C}$. IR $V_{\max }\left(\mathrm{cm}^{-1} ; \mathrm{KBr}\right.$ pellets $): 3578(\mathrm{O}-\mathrm{H}), 3309(\mathrm{~N}-\mathrm{H}), 3118$ ( $\mathrm{NH}_{2}$ amide $), 1643$ ( $\mathrm{C}=\mathrm{O}$ amide $), 1532(\mathrm{C}=\mathrm{N}$ imine $), 1371(\mathrm{~N}-\mathrm{O}$ furoxan), 1293 (C-N aromatic). ${ }^{1} \mathrm{H}$ NMR (300 MHz, DMSO-d $d_{6}$, $\delta \mathrm{ppm}) \delta: 12.15$ (1H; s), $9.80(1 \mathrm{H} ; \mathrm{s}), 8.50(1 \mathrm{H} ; \mathrm{s}), 7.99(3 \mathrm{H} ; \mathrm{m}), 7.33$ $(3 \mathrm{H} ; \mathrm{m}), 7.00(1 \mathrm{H} ; \mathrm{d} ; J=6.9 \mathrm{~Hz}) .{ }^{13} \mathrm{C}$ NMR $\left(75 \mathrm{MHz}\right.$, DMSO- $d_{6}$, $\delta \mathrm{ppm}) \delta: 163.4,157.4,144.9,134.3,129.6,119.0,118.3,114.6,113.3$. Anal. Calcd (\%) for $\mathrm{C}_{14} \mathrm{H}_{10} \mathrm{~N}_{4} \mathrm{O}_{4}$ : C: 56.38; $\mathrm{H}: 3.38 ; \mathrm{N}: 18.79$. Found: C: $56.41 ; \mathrm{H}: 3.38 ; \mathrm{N}: 18.82$.

(E)-6-((2-(4-Hydroxybenzoyl)hydrazono)methyl)benzo[c][1,2,5]oxadiazole 1-Oxide (14). Yellow powder; yield, $85 \%$; mp 280 to $281^{\circ} \mathrm{C}$. IR $V_{\max }\left(\mathrm{cm}^{-1}\right.$; KBr pellets): $3573(\mathrm{O}-\mathrm{H}), 3332(\mathrm{~N}-\mathrm{H}), 3096$ ( $\mathrm{NH}_{2}$ amide $), 1638$ ( $\mathrm{C}=\mathrm{O}$ amide $), 1523(\mathrm{C}=\mathrm{N}$ imine $), 1371(\mathrm{~N}-\mathrm{O}$ furoxan), 1280 (C-N aromatic). ${ }^{1} \mathrm{H}$ NMR (300 MHz, DMSO-d, $\delta \mathrm{ppm}) \delta: 12.02(1 \mathrm{H} ; \mathrm{s}), 10.21(1 \mathrm{H} ; \mathrm{s}), 8.47(1 \mathrm{H} ; \mathrm{s}), 8.01(2 \mathrm{H} ; \mathrm{m}), 7.83$ $(2 \mathrm{H} ; \mathrm{d} ; J=8.7 \mathrm{~Hz}), 6.87(3 \mathrm{H}$; $; J=8.7 \mathrm{~Hz}) .{ }^{13} \mathrm{C}$ NMR $(75 \mathrm{MHz}$, DMSO- $_{6}, \delta$ ppm) $\delta: 163.0,161.0,152.8,144.0,136.3,130.0,128.8$, 123.4, 118.2, 115.1, 114.8. Anal. Calcd (\%) for $\mathrm{C}_{14} \mathrm{H}_{10} \mathrm{~N}_{4} \mathrm{O}_{4}$ : C: 56.38; $\mathrm{H}: 3.38 ; \mathrm{N}: 18.79$. Found: C: $56.39 ; \mathrm{H}: 3.39 ; \mathrm{N}: 18.78$.

(E)-6-((2-(2-Aminobenzoyl)hydrazono)methyl)benzo[c][1,2,5]oxadiazole 1-Oxide (15). Yellow powder; yield, 77\%; mp 193 to $194{ }^{\circ} \mathrm{C}$. IR $V_{\max }\left(\mathrm{cm}^{-1} ; \mathrm{KBr}\right.$ pellets): $3501\left(\mathrm{NH}_{2}\right.$ amine $), 3319(\mathrm{~N}-\mathrm{H})$, 3100 ( $\mathrm{NH}_{2}$ amide), 1668 ( $\mathrm{C}=\mathrm{O}$ amide $), 1536(\mathrm{C}=\mathrm{N}$ imine $), 1477$ (N-O furoxan), 1346 (C-N aromatic). ${ }^{1} \mathrm{H}$ NMR $(300 \mathrm{MHz}, \mathrm{DMSO}-$ $\left.d_{6}, \delta \mathrm{ppm}\right) \delta: 11.98(1 \mathrm{H} ; \mathrm{s}), 8.44(1 \mathrm{H} ; \mathrm{s}), 7.93(3 \mathrm{H} ; \mathrm{m}), 7.59(1 \mathrm{H} ; \mathrm{d} ; J=$ $6.7 \mathrm{~Hz}), 7.22(1 \mathrm{H} ; \mathrm{t} ; J=7.7 \mathrm{~Hz}), 6.76(1 \mathrm{H} ; \mathrm{d} ; J=8.3 \mathrm{~Hz}), 6.58(1 \mathrm{H} ; \mathrm{d}$; $J=7.0 \mathrm{~Hz}), 6.45(2 \mathrm{H} ; \mathrm{s}) .{ }^{13} \mathrm{C}$ NMR $\left(75 \mathrm{MHz}, \mathrm{DMSO}-d_{6}, \delta \mathrm{ppm}\right)$ $\delta: 165.6,152.8,150.3,143.8,132.6,128.5,118.2,116.5,114.6,112.7$. Anal. Calcd (\%) for $\mathrm{C}_{14} \mathrm{H}_{11} \mathrm{~N}_{5} \mathrm{O}_{3}$ : C: 56.57; $\mathrm{H}: 3.73 ; \mathrm{N}: 23.56$. Found: C: $56.64 ; \mathrm{H}: 3.74 ; \mathrm{N}: 23.58$.

(E)-6-((2-(3-Aminobenzoyl)hydrazono)methyl)benzo[c][1,2,5]oxadiazole 1-Oxide (16). Yellow powder; yield, 82\%; mp 213 to $215^{\circ} \mathrm{C}$. IR $V_{\max }\left(\mathrm{cm}^{-1} ; \mathrm{KBr}\right.$ pellets $): 3501\left(\mathrm{NH}_{2}\right.$ amine $), 3232(\mathrm{~N}-\mathrm{H})$, $3100\left(\mathrm{NH}_{2}\right.$ amide $), 1638$ ( $\mathrm{C}=\mathrm{O}$ amide $), 1532(\mathrm{C}=\mathrm{N}$ imine $), 1416$ (N-O furoxan), 1312 (C-N aromatic). ${ }^{1} \mathrm{H}$ NMR (300 MHz, DMSO$\left.d_{6}, \delta \mathrm{ppm}\right) \delta: 12.31(1 \mathrm{H} ; \mathrm{s}), 8.86(1 \mathrm{H} ; \mathrm{s}), 8.53(1 \mathrm{H} ; \mathrm{s}), 8.10(3 \mathrm{H} ; \mathrm{m})$, $7.87(3 \mathrm{H} ; \mathrm{s}), 7.64(1 \mathrm{H} ; \mathrm{t} ; J=7.9 \mathrm{~Hz}), 7.57(1 \mathrm{H} ; \mathrm{d} ; J=7.3 \mathrm{~Hz}) .{ }^{13} \mathrm{C}$ NMR $\left(75 \mathrm{MHz}, \mathrm{DMSO}-d_{6}, \delta \mathrm{ppm}\right) \delta: 162.9,159.6,150.5,148.9,145.2,134.1$, 129.7, 128.9, 126.3, 124.6, 120.7, 114.7. Anal. Calcd (\%) for $\mathrm{C}_{14} \mathrm{H}_{11} \mathrm{~N}_{5} \mathrm{O}_{3}$ : C: 56.57; H: 3.73; N: 23.56. Found: C: 56.59; H: 3.73; $\mathrm{N}: 23.59$.

(E)-6-((2-(4-Aminobenzoyl)hydrazono)methyl)benzo[c][1,2,5]oxadiazole 1-Oxide (17). Yellow powder; yield, 84\%; mp 218 to $20{ }^{\circ} \mathrm{C}$. IR $V_{\max }\left(\mathrm{cm}^{-1} ; \mathrm{KBr}\right.$ pellets $): 3478\left(\mathrm{NH}_{2}\right.$ amine $), 3319(\mathrm{~N}-\mathrm{H})$, $3118\left(\mathrm{NH}_{2}\right.$ amide), 1627 ( $\mathrm{C}=\mathrm{O}$ amide), $1500(\mathrm{C}=\mathrm{N}$ imine $), 1380$ (N-O furoxan), 1252 (C-N aromatic). ${ }^{1} \mathrm{H}$ NMR (300 MHz, DMSO$\left.d_{6}, \delta \mathrm{ppm}\right) \delta: 8.44(1 \mathrm{H} ; \mathrm{s}), 7.92(3 \mathrm{H} ; \mathrm{m}), 7.69(2 \mathrm{H} ; \mathrm{d} ; J=8.6 \mathrm{~Hz}), 6.60$ $(2 \mathrm{H} ; \mathrm{d} ; J=8.6 \mathrm{~Hz}), 5.87(2 \mathrm{H} ; \mathrm{s}) .{ }^{13} \mathrm{C}$ NMR (75 MHz, DMSO- $d_{6}$, $\delta \mathrm{ppm}) \delta: 165.3,152.6,142.9,129.7,118.9,112.6$. Anal. Calcd (\%) for $\mathrm{C}_{14} \mathrm{H}_{11} \mathrm{~N}_{5} \mathrm{O}_{3}$ : C: 56.57; H: 3.73; N: 23.56. Found: C: 56.58; H: 3.74; $\mathrm{N}: 23.57$.

General Procedure for the Synthesis of Compounds 20-26. Compound 18 (0.3 g, $1.06 \mathrm{mmol})$ was dissolved in dichloromethane $(15 \mathrm{~mL})$ and then cooled by placing it on an ice bath. Next, the appropriate nitrile $(0.15 \mathrm{~g}, 1.06 \mathrm{mmol})$ and potassium carbonate $(0.18 \mathrm{~g}$, $1.32 \mathrm{mmol}$ ) were added in small portions. The reaction mixture was stirred at $40{ }^{\circ} \mathrm{C}$ for $96 \mathrm{~h}$. Afterward, the solvent was evaporated under reduced pressure and the obtained solid was dissolved in $50 \mathrm{~mL}$ of ethyl acetate and washed with water. The organic phase was dried with anhydrous magnesium sulfate, and the solvent was evaporated, giving a yellow solid. The obtained solid was purified by silica gel column chromatography using hexane and ethyl acetate $(70: 30 \mathrm{v} / \mathrm{v})$ as eluent to give the appropriate compound (20-26) in variable yields.

3-Cyano-6-(1,3-dioxolan-2-yl)-2-(p-tolyl)quinoxaline 1,4-Dioxide (20). Yellow powder; yield, $9 \%$; mp 179 to $180^{\circ} \mathrm{C}$. IR $V_{\max }\left(\mathrm{cm}^{-1} ; \mathrm{KBr}\right.$ pellets): 3090 (C-H aromatic), 2233 (CN nitrile), 1328 (N-O), 1073 (C-O ether). ${ }^{1} \mathrm{H}$ NMR $\left(400 \mathrm{MHz}, \mathrm{DMSO}-d_{6}, \delta \mathrm{ppm}\right) \delta: 8.55(2 \mathrm{H}$; t; $J=18.7 \mathrm{~Hz}), 8.12(1 \mathrm{H} ; \mathrm{d} ; J=8.8 \mathrm{~Hz}), 7.63(2 \mathrm{H} ; \mathrm{d} ; J=8.0 \mathrm{~Hz}), 7.43(2 \mathrm{H}$; $\mathrm{d} ; J=7.9 \mathrm{~Hz}), 6.10(1 \mathrm{H} ; \mathrm{s}), 4.09(4 \mathrm{H} ; \mathrm{m}), 2.43(3 \mathrm{H} ; \mathrm{s}) .{ }^{13} \mathrm{C}$ NMR $\left(75 \mathrm{MHz}, \mathrm{DMSO}-d_{6}, \delta \mathrm{ppm}\right) \delta: 143.1,143.0,141.1,136.7,132.2,130.1$, 129.2, 129.1, 124.7, 121.0, 117.7, 101.1, 65.3, 21.1. Anal. Calcd (\%) for $\mathrm{C}_{19} \mathrm{H}_{15} \mathrm{~N}_{3} \mathrm{O}_{4}$ : C: 65.32; $\mathrm{H}: 4.33$; N: 12.03. Found: C: 65.36; H: 4.32; $\mathrm{N}: 12.05$.

2-(4-Chlorophenyl)-3-cyano-6-(1,3-dioxolan-2-yl)quinoxaline 1,4-Dioxide (21). Yellow powder; yield, $13 \% ; \mathrm{mp} 177$ to $178^{\circ} \mathrm{C}$. IR $V_{\max }$ ( $\mathrm{cm}^{-1}$; $\mathrm{KBr}$ pellets): 3091 (C-H aromatic), 2235 (CN nitrile), 1330 $(\mathrm{N}-\mathrm{O}), 1093$ (C-O ether). ${ }^{1} \mathrm{H}$ NMR (400 MHz, DMSO- $d_{6}, \delta$ ppm) $\delta: 8.56(2 \mathrm{H} ; \mathrm{t} ; J=16.0 \mathrm{~Hz}), 8.12(1 \mathrm{H} ; \mathrm{dd} ; J=26.5 \mathrm{~Hz}), 7.75(4 \mathrm{H} ; \mathrm{q} ; J=$ $25.4 \mathrm{~Hz}), 6.11(1 \mathrm{H} ; \mathrm{s}), 4.09(4 \mathrm{H} ; \mathrm{m}) .{ }^{13} \mathrm{C}$ NMR $\left(75 \mathrm{MHz}, \mathrm{DMSO}-d_{6}\right.$, $\delta \mathrm{ppm}) \delta: 144.8,142.1,138.8,137.1,136.0,132.1,130.8,128.8,126.5$, 121.1, 117.7, 65.3. Anal. Calcd (\%) for $\mathrm{C}_{18} \mathrm{H}_{12} \mathrm{ClN}_{3} \mathrm{O}_{4}$ : C: 58.47; $\mathrm{H}: 3.27 ; \mathrm{N}: 11.36$. Found: C: $58.67 ; \mathrm{H}: 3.36 ; \mathrm{N}: 11.53$.

3-Cyano-6-(1,3-dioxolan-2-yl)-2-(4-methoxyphenyl)quinoxaline 1,4-Dioxide (22). Yellow powder; yield, $26 \%$; $\mathrm{mp} 151$ to $152^{\circ} \mathrm{C}$. IR $V_{\max }$ ( $\mathrm{cm}^{-1}$; $\mathrm{KBr}$ pellets): 3085 (C-H aromatic), 2236 (CN nitrile), 1335 $(\mathrm{N}-\mathrm{O}), 1095$ (C-O ether). ${ }^{1} \mathrm{H}$ NMR (400 MHz, DMSO- $d_{6}, \delta$ ppm) $\delta: 8.55(2 \mathrm{H} ; \mathrm{m}), 8.05(1 \mathrm{H} ; \mathrm{dd}), 7.71(2 \mathrm{H} ; \mathrm{d} ; J=8.8 \mathrm{~Hz}), 7.17(2 \mathrm{H} ; \mathrm{d} ; J=$ $8.7 \mathrm{~Hz}), 6.09(1 \mathrm{H} ; \mathrm{s}), 4.08(4 \mathrm{H} ; \mathrm{m}), 3.87(3 \mathrm{H} ; \mathrm{s}) .{ }^{13} \mathrm{C} \mathrm{NMR}(75 \mathrm{MHz}$, DMSO- $\left.d_{6}, \delta \mathrm{ppm}\right) \delta: 161.2,144.6,142.9,138.8,132.4,132.0,120.6$, 119.3, 118.0, 117.7, 113.9, 101.1, 65.2, 55.4. Anal. Calcd (\%) for $\mathrm{C}_{19} \mathrm{H}_{15} \mathrm{~N}_{3} \mathrm{O}_{5}$ : C: 62.46; H: 4.14; N: 11.50. Found: C: 62.51; H: 4.15; $\mathrm{N}: 11.52$.

3-Cyano-6-(1,3-dioxolan-2-yl)-2-(4-fluorophenyl)quinoxaline 1,4Dioxide (23). Yellow powder; yield, $30 \%$; mp 164 to $165^{\circ} \mathrm{C}$. IR $V_{\max }$ ( $\mathrm{cm}^{-1}$; $\mathrm{KBr}$ pellets): 3077 (C-H aromatic), 2234 (CN nitrile), 1330 $(\mathrm{N}-\mathrm{O}), 1097$ (C-O ether). ${ }^{1} \mathrm{H}$ NMR (400 MHz, DMSO- $d_{6}, \delta$ ppm) $\delta: 8.56(2 \mathrm{H} ; \mathrm{t} ; J=17.5 \mathrm{~Hz}), 8.15(1 \mathrm{H} ; \mathrm{d} ; J=10.4 \mathrm{~Hz}), 7.81(2 \mathrm{H} ; \mathrm{t} ; J=$ $14.1 \mathrm{~Hz}), 7.49(2 \mathrm{H} ; \mathrm{t} ; J=17.7 \mathrm{~Hz}), 6.10(1 \mathrm{H} ; \mathrm{s}), 4.09(4 \mathrm{H} ; \mathrm{m}) .{ }^{13} \mathrm{C}$ NMR $\left(75 \mathrm{MHz}, \mathrm{DMSO}-d_{6}, \delta \mathrm{ppm}\right) \delta: 162.2,143.2,142.3,139.1,136.7$, 133.0, 132.9, 132.3, 124.0, 121.0, 117.7, 115.7, 101.0, 65.3. Anal. Calcd (\%) for $\mathrm{C}_{18} \mathrm{H}_{12} \mathrm{FN}_{3} \mathrm{O}_{4}$ : C: 61.19; $\mathrm{H}: 3.42 ; \mathrm{N}: 11.89$. Found: C: 61.18 ; $\mathrm{H}: 3.41 ; \mathrm{N}: 11.90$.

3-Cyano-6-(1,3-dioxolan-2-yl)-2-(4-(trifluoromethoxy)phenyl)quinoxaline 1,4-Dioxide (24). Yellow powder; yield, 3\%; mp 186 to $187^{\circ} \mathrm{C}$. IR $V_{\max }\left(\mathrm{cm}^{-1} ; \mathrm{KBr}\right.$ pellets): 3077 (C-H aromatic), 2236 (CN nitrile), $1333(\mathrm{~N}-\mathrm{O}), 1165$ (C-O ether). ${ }^{1} \mathrm{H}$ NMR ( $400 \mathrm{MHz}$, DMSO$\left.d_{6}, \delta \mathrm{ppm}\right) \delta: 8.57(2 \mathrm{H} ; \mathrm{t} ; J=15.4 \mathrm{~Hz}), 8.15(1 \mathrm{H} ; \mathrm{d} ; J=8.9 \mathrm{~Hz}), 7.89$ $(2 \mathrm{H} ; \mathrm{d} ; J=8.7 \mathrm{~Hz}), 7.66(2 \mathrm{H} ; \mathrm{d} ; J=8.4 \mathrm{~Hz}), 6.11(1 \mathrm{H} ; \mathrm{s}), 4.10(4 \mathrm{H} ; \mathrm{m})$. ${ }^{13} \mathrm{C}$ NMR $\left(75 \mathrm{MHz}\right.$, DMSO- $\left.d_{6}, \delta \mathrm{ppm}\right) \delta: 149.9,143.3,141.9,139.1$, 136.8, 132.7, 132.4, 131.0, 126.7, 121.3, 121.0, 120.9, 117.7, 101.0, 65.3. Anal. Calcd (\%) for $\mathrm{C}_{19} \mathrm{H}_{12} \mathrm{~F}_{3} \mathrm{~N}_{3} \mathrm{O}_{5}: \mathrm{C}: 54.42 ; \mathrm{H}: 2.88 ; \mathrm{N}: 10.02$. Found: C: $54.47 ; \mathrm{H}: 2.88 ; \mathrm{N}: 10.06$.

3-Cyano-6-(1,3-dioxolan-2-yl)-2-(furan-2-yl)quinoxaline 1,4-Dioxide (25). Orange powder; yield, $26 \%$; mp 177 to $179{ }^{\circ} \mathrm{C}$. IR $V_{\max }$ ( $\mathrm{cm}^{-1}$; $\mathrm{KBr}$ pellets): 3087 (C-H aromatic), 2240 (CN nitrile), 1355 $(\mathrm{N}-\mathrm{O}), 1107$ (C-O ether). ${ }^{1} \mathrm{H}$ NMR (300 MHz, DMSO- $d_{6}, \delta$ ppm) $\delta: 8.57(1 \mathrm{H} ; \mathrm{dd} ; J=5.2,3.6 \mathrm{~Hz}), 8.49(1 \mathrm{H} ; \mathrm{d} ; J=8.9 \mathrm{~Hz}), 8.24(2 \mathrm{H} ; \mathrm{d}$; $J=3.5 \mathrm{~Hz}), 8.01(1 \mathrm{H} ; \mathrm{dd} ; J=8.9,1.6 \mathrm{~Hz}), 6.95(1 \mathrm{H} ; \mathrm{dd} ; J=3.6,1.8 \mathrm{~Hz})$, $6.08(1 \mathrm{H} ; \mathrm{d} ; J=3.1 \mathrm{~Hz}), 4.09(4 \mathrm{H} ; \mathrm{m}) .{ }^{13} \mathrm{C}$ NMR $\left(75 \mathrm{MHz}, \mathrm{DMSO}-d_{6}\right.$, $\delta \mathrm{ppm}) \delta: 146.8,144.7,142.3,140.2,138.5,135.6,133.4,132.3,130.0$, 120.9, 117.7, 116.8, 113.2, 111.1, 101.2, 65.3. Anal. Calcd (\%) for $\mathrm{C}_{16} \mathrm{H}_{11} \mathrm{~N}_{3} \mathrm{O}_{5}$ : C: 59.08; H: 3.41; N: 12.92. Found: C: 59.12; H: 3.42; $\mathrm{N}: 12.94$.

3-Cyano-6-(1,3-dioxolan-2-yl)-2-(thiophen-2-yl)quinoxaline 1,4Dioxide (26). Brown powder; yield, $15 \%$; $\mathrm{mp} 171$ to $173{ }^{\circ} \mathrm{C}$. IR $V_{\max }$ ( $\mathrm{cm}^{-1}$; $\mathrm{KBr}$ pellets): 3092 (C-H aromatic), 2241 (CN nitrile), 1357 $(\mathrm{N}-\mathrm{O}), 1084$ (C-O ether). ${ }^{1} \mathrm{H}$ NMR $\left(300 \mathrm{MHz}, \mathrm{DMSO}-d_{6}, \delta \mathrm{ppm}\right)$ $\delta: 8.60(1 \mathrm{H} ; \mathrm{dd} ; J=5.3,3.6 \mathrm{~Hz}), 8.51(1 \mathrm{H} ; \mathrm{d} ; J=8.8 \mathrm{~Hz}), 8.45(1 \mathrm{H} ; \mathrm{dt}$; $J=4.2,1.2 \mathrm{~Hz}), 8.13(1 \mathrm{H} ; \mathrm{dd} ; J=5.1,1.0 \mathrm{~Hz}), 8.03(1 \mathrm{H} ; \mathrm{dd} ; J=8.9$, $1.7 \mathrm{~Hz}), 7.43(1 \mathrm{H} ; \mathrm{dd} ; J=5.0,4.2 \mathrm{~Hz}), 6.09(1 \mathrm{H} ; \mathrm{d} ; J=3.8 \mathrm{~Hz}), 4.09$ $(4 \mathrm{H} ; \mathrm{m}) .{ }^{13} \mathrm{C}$ NMR $\left(75 \mathrm{MHz}, \mathrm{DMSO}-d_{6}, \delta \mathrm{ppm}\right) \delta: 145.1,142.5,138.1$, 
$137.7,136.8,135.6,132.5,130.2,127.0,126.0,120.7,117.9,112.6,101.2$, 65.1. Anal. Calcd (\%) for $\mathrm{C}_{16} \mathrm{H}_{11} \mathrm{~N}_{3} \mathrm{O}_{4}$ S: C: 56.30; $\mathrm{H}: 3.25$; N: 12.31 . Found: C: 56.31; H: 3.25; N: 12.30 .

\section{ASSOCIATED CONTENT}

\section{S Supporting Information}

The Supporting Information is available free of charge on the ACS Publications website at DOI: 10.1021/acs.jmedchem.7b01332.

Spectral characterization data, details of the methodology of all biological experiments, and microarray data (PDF) Molecular formula strings (CSV)

\section{AUTHOR INFORMATION}

\section{Corresponding Authors}

*(F.R.P.) E-mail: fernandopavan@fcfar.unesp.br. Phone: +55 16 33014667.

*(J.L.d.S.) E-mail: santosjl@fcfar.unesp.br. Phone: +55 163301 6972.

\section{ORCID}

Guilherme Felipe dos Santos Fernandes: 0000-0002-7644-5466 Elsa Moreno-Viguri: 0000-0001-6302-6230

Silvia Pérez-Silanes: 0000-0002-6284-4546

Konstantin Chegaev: 0000-0001-9962-1218

Stefano Guglielmo: 0000-0002-3313-4369

Loretta Lazzarato: 0000-0001-7100-8593

Marlus Chorilli: 0000-0002-6698-0545

Jean Leandro dos Santos : 0000-0002-2460-2829

\section{Author Contributions}

${ }^{\circ}$ G.F.d.S.F. and P.C.d.S. contributed equally to this work.

\section{Notes}

The authors declare no competing financial interest.

\section{ACKNOWLEDGMENTS}

This study was supported by the Fundação de Amparo à Pesquisa do Estado de São Paulo (FAPESP grants 2013/14957-5, 2014/ 02240-1, 2014/24811-0, 2014/11586-9, 2014/03920-6, 2015/ 19531-1, 2016/09502-7, and 2016/02860-5), Programa de Estágio no Exterior (PROPG-UNESP 2012), Conselho Nacional de Desenvolvimento Científico e Tecnológico (CNPQ grant 162676/ 2013-1), Programa de Apoio ao Desenvolvimento Científico da Faculdade de Ciências Farmacêuticas da UNESP (PADC-FCF UNESP), and the USA National Institute of Allergy and Infections Diseases (preclinical services contract HHSN2722011000091). This work was also supported by the Francis Crick Institute, which receives its core funding from Cancer Research UK (FC001060), the UK Medical Research Council (FC001060), and the Wellcome Trust (FC001060). The authors thanks Professor Alberto Gasco for his constribution to the discussion.

\section{ABBREVIATIONS USED}

DBU, 1,8-diazabicyclo[5.4.0] undec-7-ene; DCM, dichloromethane; IR, infrared spectroscopy; MDR, multidrug-resistant; MBC, minimum bactericidal concentration; Mtb, Mycobacterium tuberculosis; NMR, nuclear magnetic resonance; QdNO, quinoxaline 1,4-di-N-oxide; ROS, reactive oxygen species; REMA, Resazurin microtiter assay; RMP, rifampicin; SI, selectivity index; TB, tuberculosis; WHO, World Health Organization

\section{REFERENCES}

(1) Global Tuberculosis Report 2016; World Health Organization: Geneva, Switzerland, 2016.

(2) Global Tuberculosis Report 2013; World Health Organization: Geneva, Switzerland, 2013.

(3) Rustad, T. R.; Harrell, M. I.; Liao, R.; Sherman, D. R. The Enduring Hypoxic Response of Mycobacterium Tuberculosis. PLoS One 2008, 3 (1), e1502.

(4) Patel, K.; Jhamb, S. S.; Singh, P. P. Models of Latent Tuberculosis: Their Salient Features, Limitations, and Development. J. Lab. Physicians 2011, 3 (2), 75-79.

(5) Zumla, A.; Nahid, P.; Cole, S. T. Advances in the Development of New Tuberculosis Drugs and Treatment Regimens. Nat. Rev. Drug Discovery 2013, 12 (5), 388-404.

(6) Klopper, M.; Warren, R. M.; Hayes, C.; van Pittius, N. C. G.; Streicher, E. M.; Muller, B.; Sirgel, F. A.; Chabula-Nxiweni, M.; Hoosain, E.; Coetzee, G.; van Helden, P. D.; Victor, T. C.; Trollip, A. P. Emergence and Spread of Extensively and Totally Drug-Resistant Tuberculosis, South Africa. Emerging Infect. Dis. 2013, 19 (3), 449-455.

(7) Slomski, A. South Africa Warns of Emergence of " Totally " DrugResistant Tuberculosis. JAMA J. Am. Med. Assoc. 2013, 309 (11), 10971098.

(8) Multidrug and Extensively Drug-Resistant TB (M/XDR-TB): 2010 Global Report on Surveillance and Response; World Health Organization: Geneva, Switzerland, 2010.

(9) Zumla, A.; Chakaya, J.; Centis, R.; D’Ambrosio, L.; Mwaba, P.; Bates, M.; Kapata, N.; Nyirenda, T.; Chanda, D.; Mfinanga, S.; Hoelscher, M.; Maeurer, M.; Migliori, G. B. Tuberculosis Treatment and Management-an Update on Treatment Regimens, Trials, New Drugs, and Adjunct Therapies. Lancet Respir. Med. 2015, 3 (3), 220-234.

(10) Ma, Z.; Lienhardt, C.; McIlleron, H.; Nunn, A. J.; Wang, X. Global Tuberculosis Drug Development Pipeline: The Need and the Reality. Lancet 2010, 375 (9731), 2100-2109.

(11) Global Tuberculosis Report 2014 (WHO/HTM/TB/2014.08); World Health Organization: Geneva, Switzerland, 2014.

(12) Frydenberg, A. R.; Graham, S. M. Toxicity of First-Line Drugs for Treatment of Tuberculosis in Children: Review. Trop. Med. Int. Health 2009, 14 (11), 1329-1337.

(13) Tasduq, S. A.; Kaiser, P.; Sharma, S. C.; Johri, R. K. Potentiation of Isoniazid-Induced Liver Toxicity by Rifampicin in a Combinational Therapy of Antitubercular Drugs (Rifampicin, Isoniazid and Pyrazinamide) in Wistar Rats: A Toxicity Profile Study. Hepatol. Res. 2007, 37 (10), 845-853.

(14) Singh, M.; Sasi, P.; Rai, G.; Gupta, V. H.; Amarapurkar, D.; Wangikar, P. P. Studies on Toxicity of Antitubercular Drugs Namely Isoniazid, Rifampicin, and Pyrazinamide in an in Vitro Model of HepG2 Cell Line. Med. Chem. Res. 2011, 20 (9), 1611-1615.

(15) Yee, D.; Valiquette, C.; Pelletier, M.; Parisien, I.; Rocher, I.; Menzies, D. Incidence of Serious Side Effects from First-Line Antituberculosis Drugs among Patients Treated for Active Tuberculosis. Am. J. Respir. Crit. Care Med. 2003, 167 (11), 1472-1477.

(16) Sahasrabudhe, V.; Zhu, T.; Vaz, A.; Tse, S. Drug Metabolism and Drug Interactions: Potential Application to Antituberculosis Drugs. J. Infect. Dis. 2015, 211, S107-S114.

(17) Saxena, S.; Samala, G.; Sridevi, J. P.; Devi, P. B.; Yogeeswari, P.; Sriram, D. Design and Development of Novel Mycobacterium Tuberculosis L-Alanine Dehydrogenase Inhibitors. Eur. J. Med. Chem. 2015, 92, 401-414.

(18) Baldwin, P. R.; Reeves, A. Z.; Powell, K. R.; Napier, R. J.; Swimm, A. I.; Sun, A.; Giesler, K.; Bommarius, B.; Shinnick, T. M.; Snyder, J. P.; Liotta, D. C.; Kalman, D. Monocarbonyl Analogs of Curcumin Inhibit Growth of Antibiotic Sensitive and Resistant Strains of Mycobacterium Tuberculosis. Eur. J. Med. Chem. 2015, 92, 693-699.

(19) Ng, P. S.; Manjunatha, U. H.; Rao, S. P. S.; Camacho, L. R.; Ma, N. L.; Herve, M.; Noble, C. G.; Goh, A.; Peukert, S.; Diagana, T. T.; Smith, P. W.; Kondreddi, R. R. Structure Activity Relationships of 4-Hydroxy2-Pyridones: A Novel Class of Antituberculosis Agents. Eur. J. Med. Chem. 2015, 106, 144-156. 
(20) dos Santos Fernandes, G. F.; Man Chin, C.; dos Santos, J. L. Advances in Drug Discovery of New Antitubercular Multidrug-Resistant Compounds. Pharmaceuticals 2017, 10 (2), 51.

(21) dos Santos Fernandes, G. F.; Jornada, D. H.; de Souza, P. C.; Man Chin, C.; Pavan, F. R; dos Santos, J. L. Current Advances in Antitubercular Drug Discovery: Potent Prototypes and New Targets. Curr. Med. Chem. 2015, 22 (27), 3133-3161.

(22) Wallis, R. S.; Maeurer, M.; Mwaba, P.; Chakaya, J.; Rustomjee, R.; Migliori, G. B.; Marais, B.; Schito, M.; Churchyard, G.; Swaminathan, S.; Hoelscher, M.; Zumla, A. Tuberculosis-advances in Development of New Drugs, Treatment Regimens, Host-Directed Therapies, and Biomarkers. Lancet Infect. Dis. 2016, 16 (4), e34-e46.

(23) Bloemberg, G. V.; Keller, P. M.; Stucki, D.; Trauner, A.; Borrell, S.; Latshang, T.; Coscolla, M.; Rothe, T.; Hömke, R.; Ritter, C.; Feldmann, J.; Schulthess, B.; Gagneux, S.; Böttger, E. C. Acquired Resistance to Bedaquiline and Delamanid in Therapy for Tuberculosis. N. Engl. J. Med. 2015, 373 (20), 1986-1988.

(24) Zhang, S.; Chen, J.; Cui, P.; Shi, W.; Shi, X.; Niu, H.; Chan, D.; Yew, W. W.; Zhang, W.; Zhang, Y. Mycobacterium Tuberculosis Mutations Associated with Reduced Susceptibility to Linezolid. Antimicrob. Agents Chemother. 2016, 60 (4), 2542-2544.

(25) Segala, E.; Sougakoff, W.; Nevejans-Chauffour, A.; Jarlier, V.; Petrella, S. New Mutations in the Mycobacterial ATP Synthase: New Insights into the Binding of the Diarylquinoline TMC207 to the ATP Synthase C-Ring Structure. Antimicrob. Agents Chemother. 2012, 56 (5), 2326-2334.

(26) dos Santos Fernandes, G. F.; de Souza, P. C.; Marino, L. B.; Chegaev, K.; Guglielmo, S.; Lazzarato, L.; Fruttero, R.; Chung, M. C.; Pavan, F. R.; dos Santos, J. L. Synthesis and Biological Activity of Furoxan Derivatives against Mycobacterium Tuberculosis. Eur. J. Med. Chem. 2016, 123, 523-531.

(27) Cerecetto, H.; Porcal, W. Pharmacological Properties of Furoxans and Benzofuroxans: Recent Developments. Mini-Rev. Med. Chem. 2005, 5 (1), 57-71.

(28) Hernández, P.; Rojas, R.; Gilman, R. H.; Sauvain, M.; Lima, L. M.; Barreiro, E. J.; González, M.; Cerecetto, H. Hybrid Furoxanyl NAcylhydrazone Derivatives as Hits for the Development of Neglected Diseases Drug Candidates. Eur. J. Med. Chem. 2013, 59, 64-74.

(29) Gasco, A.; Fruttero, R.; Sorba, G.; Di Stilo, A.; Calvino, R. NO Donors: Focus on Furoxan Derivatives. Pure Appl. Chem. 2004, 76 (5), 973-981.

(30) Castro, D.; Boiani, L.; Benitez, D.; Hernandez, P.; Merlino, A.; Gil, C.; Olea-Azar, C.; Gonzalez, M.; Cerecetto, H.; Porcal, W. AntiTrypanosomatid Benzofuroxans and Deoxygenated Analogues: Synthesis Using Polymer-Supported Triphenylphosphine, Biological Evaluation and Mechanism of Action Studies. Eur. J. Med. Chem. 2009, 44 (12), 5055-5065.

(31) Olea-Azar, C.; Rigol, C.; Mendizabal, F.; Cerecetto, H.; Di Maio, R.; Gonzalez, M.; Porcal, W.; Morello, A.; Repetto, Y.; Maya, J. D. Novel Benzo[1,2-c]1,2,5-Oxadiazole N-Oxide Derivatives as Antichagasic Agents: Chemical and Biological Studies. Lett. Drug. Des. Discovery 2005, 2, 294-301.

(32) Suter, W.; Rosselet, A.; Knüsel, F. Mode of Action of Quindoxin and Substituted Quinoxaline-Di-N-Oxides on Escherichia Coli. Antimicrob. Agents Chemother. 1978, 13 (5), 770-783.

(33) Ganley, B.; Chowdhury, G.; Bhansali, J.; Daniels, J. S.; Gates, K. S. Redox-Activated, Hypoxia-Selective DNA Cleavage by Quinoxaline 1,4Di-N-Oxide. Bioorg. Med. Chem. 2001, 9 (9), 2395-2401.

(34) Cheng, G.; Sa, W.; Cao, C.; Guo, L.; Hao, H.; Liu, Z.; Wang, X.; Yuan, Z. Quinoxaline 1,4-Di-N-Oxides: Biological Activities and Mechanisms of Actions. Front. Pharmacol. 2016, 7, 64.

(35) Allen, D. M.; Chng, H. H. Disseminated Mycobacterium Flavescens in a Probable Case of Chronic Granulomatous Disease. J. Infect. 1993, 26, 83-86.

(36) Ohga, S.; Ikeuchi, K.; Kadoya, R.; Okada, K.; Miyazaki, C.; Suita, S.; Ueda, K. Intrapulmonary Mycobacterium Avium Infection as the First Manifestation of Chronic Granulomatous Disease. J. Infect. 1997, 34 (2), 147-150.
(37) Mestre, O.; Hurtado-Ortiz, R.; Dos Vultos, T.; Namouchi, A.; Cimino, M.; Pimentel, M.; Neyrolles, O.; Gicquel, B. High Throughput Phenotypic Selection of Mycobacterium Tuberculosis Mutants with Impaired Resistance to Reactive Oxygen Species Identifies Genes Important for Intracellular Growth. PLoS One 2013, 8 (1), e53486.

(38) Voskuil, M. I.; Bartek, I. L.; Visconti, K.; Schoolnik, G. K. The Response of Mycobacterium Tuberculosis to Reactive Oxygen and Nitrogen Species. Front. Microbiol. 2011, 2, 105.

(39) Behar, S. M.; Martin, C. J.; Booty, M. G.; Nishimura, T.; Zhao, X.; Gan, H.-X.; Divangahi, M.; Remold, H. G. Apoptosis Is an Innate Defense Function of Macrophages against Mycobacterium Tuberculosis. Mucosal Immunol. 2011, 4 (3), 279-287.

(40) Perskvist, N.; Long, M.; Stendahl, O.; Zheng, L. Mycobacterium Tuberculosis Promotes Apoptosis in Human Neutrophils by Activating Caspase-3 and Altering Expression of Bax/Bcl-X. J. Immunol. 2002, 168 (18), 6358-6365.

(41) Herbst, S.; Schaible, U. E.; Schneider, B. E. Interferon Gamma Activated Macrophages Kill Mycobacteria by Nitric Oxide Induced Apoptosis. PLoS One 2011, 6 (5), e19105.

(42) Dharmaraja, A. T.; Alvala, M.; Sriram, D.; Yogeeswari, P.; Chakrapani, H. Design, Synthesis and Evaluation of Small Molecule Reactive Oxygen Species Generators as Selective Mycobacterium Tuberculosis Inhibitors. Chem. Commun. 2012, 48 (83), 10325-10327.

(43) Fang, F. C. Antimicrobial Reactive Oxygen and Nitrogen Species: Concepts and Controversies. Nat. Rev. Microbiol. 2004, 2 (10), 820832.

(44) Long, R.; Light, B.; Talbot, J. A. Mycobacteriocidal Action of Exogenous Nitric Oxide. Antimicrob. Agents Chemother. 1999, 43 (2), 403-405.

(45) Di Stilo, A.; Visentin, S.; Cena, C.; Gasco, A. M.; Ermondi, G.; Gasco, A. New 1,4-Dihydropyridines Conjugated to Furoxanyl Moieties, Endowed with Both Nitric Oxide-like and Calcium Channel Antagonist Vasodilator Activities. J. Med. Chem. 1998, 41 (27), 53935401.

(46) Maksimovic-Ivanic, D.; Mijatovic, S.; Harhaji, L.; Miljkovic, D.; Dabideen, D.; Fan Cheng, K.; Mangano, K.; Malaponte, G.; Al-Abed, Y.; Libra, M.; Garotta, G.; Nicoletti, F.; Stosic-Grujicic, S. Anticancer Properties of the Novel Nitric Oxide-Donating Compound (S,R)-3Phenyl-4,5-Dihydro-5-Isoxazole Acetic Acid-Nitric Oxide in Vitro and in Vivo. Mol. Cancer Ther. 2008, 7 (3), 510-520.

(47) Dutra, L. A.; de Almeida, L.; Passalacqua, T. G.; Reis, J. S.; Torres, F. A. E.; Martinez, I.; Peccinini, R. G.; Chin, C. M.; Chegaev, K.; Guglielmo, S.; Fruttero, R.; Graminha, M. A. S.; dos Santos, J. L. Leishmanicidal Activities of Novel Synthetic Furoxan and Benzofuroxan Derivatives. Antimicrob. Agents Chemother. 2014, 58 (8), 4837-4847.

(48) Ghosh, P. B.; Whitehouse, M. W. Potential Antileukemic and Immunosuppressive Drugs. Preparation and in Vitro Pharmacological Activity of Some Benzo-2,1,3-Oxadiazoles (Benzofurazans) and Their N-Oxides (Benzofuroxans). J. Med. Chem. 1968, 11, 305-311.

(49) Wuts, P. G. M.; Greene, T. W. Protection for the Carbonyl Group. In Greene's Protective Groups in Organic Synthesis; Wiley-Interscience: New York, 2006; pp 431-532.

(50) Haddadin, M. J.; Issidorides, C. H. Application of Benzofurazan Oxide to the Synthesis of Heteroaromatic N-Oxides. Heterocycles 1976, 4 (4), 767-816.

(51) Haddadin, M. J.; Issidorides, C. H. Enamines with Isobenzofuroxan: A Novel Synthesis of Quinoxaline-Di-N-Oxides. Tetrahedron Lett. 1965, 6 (36), 3253-3256.

(52) Issidorides, C. H.; Haddadin, M. J. Benzofurazan Oxide. II. Reactions with Enolate Anions. J. Org. Chem. 1966, 31, 4067-4068.

(53) Zarranz, B.; Jaso, A.; Aldana, I.; Monge, A.; Maurel, S.; Deharo, E.; Jullian, V.; Sauvain, M. Synthesis and Antimalarial Activity of New 3Arylquinoxaline-2-Carbonitrile Derivatives. Arzneim. Forsch. 2005, 55 (12), 754-761.

(54) dos Santos Fernandes, G. F.; Moreno-Viguri, E.; Santivañez-Veliz, M.; Paucar, R.; Chin, C. M.; Pérez-Silanes, S.; dos Santos, J. L. A Comparative Study of Conventional and Microwave-Assisted Synthesis of Quinoxaline 1,4-Di-N-Oxide N-Acylhydrazones Derivatives De- 
signed as Antitubercular Drug Candidates. J. Heterocycl. Chem. 2017, 54 (4), 2380-2388.

(55) Palomino, J.; Martin, A.; Camacho, M.; Guerra, H.; Swings, J.; Portaels, F. Resazurin Microtiter Assay Plate: Simple and Inexpensive Method for Detection of Drug Resistance in Mycobacterium Tuberculosis Resazurin Microtiter Assay Plate: Simple and Inexpensive Method for Detection of Drug Resistance in Mycobacterium Tuberculosis. Antimicrob. Agents Chemother. 2002, 46 (8), 2720-2722.

(56) Pavan, F. R.; Maia, P. I. D. S.; Leite, S. R. a; Deflon, V. M.; Batista, A. a.; Sato, D. N.; Franzblau, S. G.; Leite, C. Q. F. Thiosemicarbazones, Semicarbazones, Dithiocarbazates and Hydrazide/hydrazones: Anti Mycobacterium Tuberculosis Activity and Cytotoxicity. Eur. J. Med. Chem. 2010, 45 (5), 1898-1905.

(57) Orme, I. Search for New Drugs for Treatment of Tuberculosis. Antimicrob. Agents Chemother. 2001, 45 (7), 1943-1946.

(58) Cho, S. H.; Warit, S.; Wan, B.; Hwang, C. H.; Pauli, G. F.; Franzblau, S. G. Low-Oxygen-Recovery Assay for High-Throughput Screening of Compounds against Nonreplicating Mycobacterium Tuberculosis. Antimicrob. Agents Chemother. 2007, 51 (4), 1380-1385.

(59) Collins, L. A.; Franzblau, S. G. Microplate Alamar Blue Assay versus BACTEC 460 System for High-Throughput Screening of Compounds against Mycobacterium Tuberculosis and Mycobacterium Avium. Antimicrob. Agents Chemother. 1997, 41 (5), 1004-1009.

(60) Piddington, D. L.; Kashkouli, A.; Buchmeier, N. A. Growth of Mycobacterium Tuberculosis in a Defined Medium Is Very Restricted by Acid $\mathrm{pH}$ and $\mathrm{Mg} 2+$ Levels. Infect. Immun. 2000, 68 (8), 4518-4522.

(61) Katila, M. L.; Mattila, J.; Brander, E. Enhancement of Growth of Mycobacterium Malmoense by Acidic $\mathrm{pH}$ and Pyruvate. Eur. J. Clin. Microbiol. Infect. Dis. 1989, 8 (11), 998-1000.

(62) Artigas, A.; Wernerman, J.; Arroyo, V.; Vincent, J. L.; Levy, M. Role of Albumin in Diseases Associated with Severe Systemic Inflammation: Pathophysiologic and Clinical Evidence in Sepsis and in Decompensated Cirrhosis. J. Crit. Care 2016, 33, 62-70.

(63) Bertucci, C.; Domenici, E. Reversible and Covalent Binding of Drugs to Human Serum Albumin: Methodological Approaches and Physiological Relevance. Curr. Med. Chem. 2002, 9 (15), 1463-1481.

(64) De Freitas, E. S.; Da Silva, P. B.; Chorilli, M.; Batista, A. A.; De Oliveira Lopes, É.; Da Silva, M. M.; Leite, C. Q. F.; Pavan, F. R. Nanostructured Lipid Systems as a Strategy to Improve the in Vitro Cytotoxicity of ruthenium(II) Compounds. Molecules 2014, 19 (5), 5999-6008.

(65) Boshoff, H. I. M.; Myers, T. G.; Copp, B. R.; McNeil, M. R.; Wilson, M. A.; Barry, C. E. The Transcriptional Responses of Mycobacterium Tuberculosis to Inhibitors of Metabolism. J. Biol. Chem. 2004, 279 (38), 40174-40184.

(66) Snewin, V. A.; Gares, M. P.; Gaora, P.; Hasan, Z.; Brown, I. N.; Young, D. B. Assessment of Immunity to Mycobacterial Infection with Luciferase Reporter Constructs. Infect. Immun. 1999, 67 (9), 45864593.

(67) Bapela, N. B.; Lall, N.; Fourie, P. B.; Franzblau, S. G.; Van Rensburg, C. E. J. Activity of 7-Methyljuglone in Combination with Antituberculous Drugs against Mycobacterium Tuberculosis. Phytomedicine 2006, 13 (9-10), 630-635.

(68) Scior, T.; Garcés-Eisele, S. J. Isoniazid Is Not a Lead Compound for Its Pyridyl Ring Derivatives, Isonicotinoyl Amides, Hydrazides, and Hydrazones: A Critical Review. Curr. Med. Chem. 2006, 13 (18), 22052219.

(69) Straniero, V.; Pallavicini, M.; Chiodini, G.; Zanotto, C.; Volonte, L.; Radaelli, A.; Bolchi, C.; Fumagalli, L.; Sanguinetti, M.; Menchinelli, G.; Delogu, G.; Battah, B.; De Giuli Morghen, C.; Valoti, E. 3(Benzodioxan-2-Ylmethoxy)-2,6-Difluorobenzamides Bearing Hydrophobic Substituents at the 7-Position of the Benzodioxane Nucleus Potently Inhibit Methicillin-Resistant Sa and Mtb Cell Division. Eur. J. Med. Chem. 2016, 120, 227-243.

(70) Wube, A. A.; Bucar, F.; Hochfellner, C.; Blunder, M.; Bauer, R.; Hüfner, A. Synthesis of N-Substituted 2-[(1E)-Alkenyl]-4-(1H)Quinolone Derivatives as Antimycobacterial Agents against NonTubercular Mycobacteria. Eur. J. Med. Chem. 2011, 46, 2091-2101.
(71) Ganihigama, D. U.; Sureram, S.; Sangher, S.; Hongmanee, P.; Aree, T.; Mahidol, C.; Ruchirawat, S.; Kittakoop, P. Antimycobacterial Activity of Natural Products and Synthetic Agents: Pyrrolodiquinolines and Vermelhotin as Anti-Tubercular Leads against Clinical Multidrug Resistant Isolates of Mycobacterium Tuberculosis. Eur. J. Med. Chem. 2015, 89, 1-12.

(72) Vandal, O. H.; Nathan, C. F.; Ehrt, S. Acid Resistance in Mycobacterium Tuberculosis. J. Bacteriol. 2009, 191 (15), 4714-4721.

(73) Dutta, N. K.; Karakousis, P. C. Latent Tuberculosis Infection: Myths, Models, and Molecular Mechanisms. Microbiol. Mol. Biol. Rev. 2014, 78 (3), 343-371.

(74) Test No. 117: Partition Coefficient (N-Octanol/water), HPLC Method. OECD Guidelines for the Testing of Chemicals; OECD Publishing: Paris, 2004; pp 1-11. 